\title{
A cross-linguistic study of the acquisition of clitic and pronoun production
}

Spyridoula Varlokosta, Adriana Belletti, João Costa, Naama Friedmann, Anna Gavarró, Kleanthes K. Grohmann, Maria Teresa Guasti, Laurice Tuller, Maria Lobo, Darinka Anđelković, Núria Argemí, Larisa Avram, Sanne Berends, Valentina Brunetto, Hélène Delage, María-José Ezeizabarrena, Iris Fattal, Ewa Haman, Angeliek van Hout, Kristine Jensen de López, Napoleon Katsos, Lana Kologranic, Nadezda Krstić, Jelena Kuvac Kraljevic, Aneta Miękisz, Michaela Nerantzini, Clara Queraltó, Zeljana Radic, Sílvia Ruiz, Uli Sauerland, Anca Sevcenco, Magdalena Smoczyńska, Eleni Theodorou, Heather van der Lely, Alma Veenstra, John Weston, Maya Yachini \& Kazuko Yatsushiro

To cite this article: Spyridoula Varlokosta, Adriana Belletti, João Costa, Naama Friedmann, Anna Gavarró, Kleanthes K. Grohmann, Maria Teresa Guasti, Laurice Tuller, Maria Lobo, Darinka Anđelković, Núria Argemí, Larisa Avram, Sanne Berends, Valentina Brunetto, Hélène Delage, María-José Ezeizabarrena, Iris Fattal, Ewa Haman, Angeliek van Hout, Kristine Jensen de López, Napoleon Katsos, Lana Kologranic, Nadezda Krstić, Jelena Kuvac Kraljevic, Aneta Miękisz, Michaela Nerantzini, Clara Queraltó, Zeljana Radic, Sílvia Ruiz, Uli Sauerland, Anca Sevcenco, Magdalena Smoczyńska, Eleni Theodorou, Heather van der Lely, Alma Veenstra, John Weston, Maya Yachini \& Kazuko Yatsushiro (2016) A cross-linguistic study of the acquisition of clitic and pronoun production, Language Acquisition, 23:1, 1-26, DOI: 10.1080/10489223.2015.1028628

To link to this article: http://dx.doi.org/10.1080/10489223.2015.1028628

Published online: 28 May 2015.

Submit your article to this journal

III Article views: 314

Q View related articles $\sqsubset$

View Crossmark data \lceil 
Full Terms \& Conditions of access and use can be found at http://www.tandfonline.com/action/journallnformation?journalCode=hlac20 


\section{A cross-linguistic study of the acquisition of clitic and pronoun production}

Spyridoula Varlokosta ${ }^{a}$, Adriana Bellettib João Costac, Naama Friedmann ${ }^{\mathrm{d}}$, Anna Gavarró, Kleanthes K. Grohmannf, Maria Teresa Guasti ${ }^{g}$, Laurice Tuller ${ }^{\mathrm{h}}$, Maria Loboc, Darinka Anđelkovići, Núria Argemíe, Larisa Avramj, Sanne Berendsk ${ }^{k}$ Valentina Brunettob, Hélène Delagel, María-José Ezeizabarrena ${ }^{m}$, Iris Fattall ${ }^{\mathrm{d}}$, Ewa Haman ${ }^{\mathrm{n}}$, Angeliek van Hout ${ }^{\mathrm{k}}$, Kristine Jensen de López ${ }^{\circ}$, Napoleon Katsos ${ }^{p}$, Lana Kologranic ${ }^{q}$, Nadezda Krstići, Jelena Kuvac Kraljevic ${ }^{q}$, Aneta Miękisz ${ }^{n}$, Michaela Nerantzinia ${ }^{a}$ Clara Queraltóe, Zeljana Radic ${ }^{q}$,

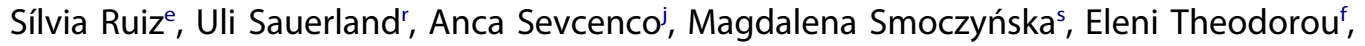
Heather van der Lely ${ }^{t}$, Alma Veenstra ${ }^{u}$, John Westonv ${ }^{v}$, Maya Yachini ${ }^{d}$ and Kazuko Yatsushiro ${ }^{r}$

aUniversity of Athens; bUniversity of Siena; 'Universidade Nova de Lisboa; dTel Aviv University; eUniversitat Autònoma de Barcelona; fUniversity of Cyprus; ' ${ }^{\prime}$ University of Milano-Bicocca; ' 'Université François-Rabelais, Tours; 'University of Belgrade; 'University of Bucharest; ' ${ }^{2}$ nniversity of Groningen; 'University of Geneva; 'mniversity of the Basque

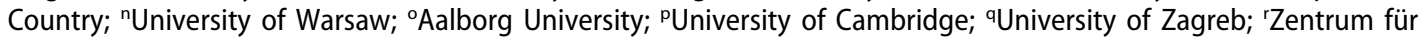

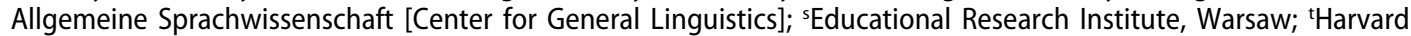
University and Université Catholique de Louvain; "University of Groningen and Max Planck Institute for Psycholinguistics; 'Queen Mary, University of London

\begin{abstract}
This study develops a single elicitation method to test the acquisition of third-person pronominal objects in 5-year-olds for 16 languages. This methodology allows us to compare the acquisition of pronominals in languages that lack object clitics ("pronoun languages") with languages that employ clitics in the relevant context ("clitic languages"), thus establishing a robust cross-linguistic baseline in the domain of clitic and pronoun production for 5 -year-olds. High rates of pronominal production are found in our results, indicating that children have the relevant pragmatic knowledge required to select a pronominal in the discourse setting involved in the experiment as well as the relevant morphosyntactic knowledge involved in the production of pronominals. It is legitimate to conclude from our data that a child who at age 5 is not able to produce any or few pronominals is a child at risk for language impairment. In this way, pronominal production can be taken as a developmental marker, provided that one takes into account certain crosslinguistic differences discussed in the article.
\end{abstract}

\section{ARTICLE HISTORY}

Received 19 July 2012

Accepted 20 February 2015

\section{Introduction}

In this study, we explore the acquisition of pronominal objects in 16 languages. The comprehension of pronominal elements has been intensively studied in a variety of typologically diverse languages. These

CONTACT Spyridoula Varlokosta svarlokosta@phil.uoa.gr 0 University of Athens, Philology/Linguistics, Panepistimioupoli Zografou, Athens, 15784 Greece.

The research reported in this paper was undertaken within COST Action A33 (PI and chair: Uli Sauerland; vice chair: Heather van der Lely). Spyridoula Varlokosta was the coordinator of the working group that undertook the research reported in this article within COST Action A33 (WG1 - Binding) and contributed to test design, data collection and analysis, and writing up. Adriana Belletti, João Costa, Naama Friedmann, Anna Gavarró, Kleanthes K. Grohmann, Maria Teresa Guasti, and Laurice Tuller contributed to test design, data collection and analysis, and writing up; they are listed alphabetically. Maria Lobo contributed to test design as well as data collection and analysis. The rest of the authors provided descriptions of the pronominal systems in the languages tested, translated the experimental materials into their own language, or contributed to collection and analysis of their own language data; they are listed alphabetically. Color versions of one or more of the figures in the article can be found online at www.tandfonline.com/hlac. 
studies indicate that, in some languages, young children interpret pronominals differently from adults. A clear asymmetry has been found between the interpretation of pronouns and clitics, however. Children allow a local interpretation of the personal pronoun, whereas they interpret clitics in a targetlike manner, i.e., not allowing a local antecedent for the (nonreflexive) clitic, already at the age of 3 (Chien \& Wexler 1990; McKee 1992; Baauw, Coopmans \& Philip 1999; Varlokosta 2000, among others). The comparison between pronouns and clitics in production has not received as much attention. Specifically, third-person object pronominal elements have been studied mainly in clitic languages (that is, languages that have clitics in addition to nonclitic pronominal elements), without comparison to pronoun languages (languages lacking clitic pronouns) (but see Bloom 1990; Grüter 2006, 2007; Pérez-Leroux, Pirvulescu \& Roberge $2008 \mathrm{~b}$, for a comparison between clitic and pronoun languages). These studies have not always used the same methods; for example, some of the results for some of the languages stem from spontaneous speech, which is not directly comparable to data from elicitation tasks.

Here, we developed a single elicitation method that was used to test the acquisition of third-person pronominal objects in 5-year-olds for 16 languages. ${ }^{1}$ This allowed for a direct comparison of languages that differ in how they express pronominal arguments. This methodology allowed us to compare the acquisition of pronominals in languages that lack object clitics (pronoun languages) with languages that employ clitics in the relevant context (clitic languages), thus establishing a robust cross-linguistic baseline in the domain of clitic and pronoun production at the same stage of language development. ${ }^{2}$ This is particularly important given the relevance of clitic production to detecting specific language impairments (SLI). Omission of thirdperson clitics or lack of clitic production in obligatory contexts has been claimed to be a clinical marker of SLI in French (e.g., Paradis, Crago \& Genesee 2003), Greek (Stavrakaki \& van der Lely 2010; Tsimpli \& Stavrakaki 1999; but, for different claims, see Manika, Varlokosta \& Wexler 2011; Varlokosta, Konstantzou \& Nerantzini 2014), and Italian (Bortolini et al. 2006). We do not know whether such omissions are limited to clitics or extend to all types of pronominals. In fact, differences in the expression of pronominal direct objects across several linguistic dimensions might lead to different performance in their production in typical and atypical language-developing children. These differences between clitics and pronouns can be found at the phonological, morphological, syntactic, and semantic levels (Kayne 1975; Zwicky 1977). On the phonological side, clitics are unstressed monosyllabic elements, in contrast to pronouns, which may receive stress and can include more than a single syllable. As for their acquisition, according to some theories, less salient phonological elements may be harder to acquire (Gerken 1996; Vanderweide 2005). This approach would predict better production of (stressed) pronouns compared to clitics. At the morphological level, object clitics are typically homophonous with definite articles or are otherwise related to a full pronominal form. Additionally, at the syntactic level, clitics are heads that cannot stand on their own and need to attach to an appropriate host. A further syntactic difference among pronominal elements relates to their distribution: Pronouns have the same distribution as full nominals (DPs), whereas clitics need a "special position," depending on the aforementioned "appropriate host"-this can be the inflected verb (leading to preverbal proclisis or postverbal enclisis in the languages included in our study) or another element (such as the second-position clitics found in many Slavic languages). Object clitics can thus occupy a position different from that of canonical object DPs. On the semantic side, clitics may refer to human and nonhuman or inanimate objects, while pronouns typically refer to humans/animate.

These differences have lead Cardinaletti \& Starke (1999) to propose a tripartition into clitic, weak, and strong pronouns across languages. An essential feature of this tripartition is that weak pronouns have an intermediate status between strong pronouns and clitics. Like strong pronouns, they fill syntactic positions

\footnotetext{
${ }^{1}$ Our choice for testing only 5 -year-olds was determined by the fact that our objective was to discover suitable test methods that can be used for diagnosing language problems and impairment in children of school-entry (i.e., age 5 to 6 ) in these 16 languages, since at the age of school-entry, an assessment of language problems and impairment has great practical importance.

${ }^{2}$ Clitics and pronouns have the same pragmatic function because they have the same information structure status: They are used as anaphoric forms when the antecedent is clear from the context. In Gundel, Hedberg \& Zacharski's (1993) Givenness Hierarchy, elements that are in focus (in a given discourse) are highest on the hierarchy. These are expressed as pronouns in pronoun languages and clitics in clitic languages.
} 
reserved for maximal projections in the clause structure (DP positions for direct object pronouns), whereas clitics ultimately fill a head position (they incorporate within the inflected verbal head in Romance languages, for example). Like clitics, phonologically weak pronouns do not carry independent stress (as mentioned before). Hence, weak pronouns may be seen as phonological clitics but not as syntactic clitics, which have a head status. As indicated by Germanic languages (such as German), strong and weak pronouns may be largely homophonous. Hence, their distinction is only detectable through their different syntactic and phonological behavior. Without committing ourselves to any specific analysis of cliticization (see Belletti 1999; Sportiche 1996, among others), we can safely assume that pronominal clitics may be considered the weakest form of pronouns in that at the end of the cliticization process the clitic ultimately is a head and incorporates/forms a word with the verb that hosts it. In contrast, both weak and strong pronouns maintain the distribution of a maximal projection and thus can be considered less weak in the relevant sense. In this article we will consider clitics and pronouns, without capitalizing on the further weak/strong partition, as the relevant distinction in the test utilized ultimately hinges on the head versus maximal projection status of the pronominal element. The tripartition proposed by Cardinaletti \& Starke (1999) has been challenged theoretically by Gabriel \& Müller (2005) and empirically by Schmitz \& Müller (2008), who show that within the group of clitic pronouns a distinction must be made with respect to their complexity, which allows to explain acquisition asymmetries between subject and object clitics in French. However, given that the research reported in this article is about direct object clitics, we do not address this issue further, since this would take the discussion too far afield, as the issues concerning subject clitics in French are rather complicated (see Hamann \& Belletti 2006 for further relevant discussion).

Previous studies on clitic production lead to the following generalizations:

(i) Children omit clitics in some languages.

Broadly speaking, clitic omission up to at least 4 or 5 years is found to different extents for Catalan (Wexler, Gavarró \& Torrens 2004; Gavarró, Torrens \& Wexler 2010), (European) Portuguese (Costa \& Lobo 2006), French (Jakubowicz et al. 1996; Hamann, Rizzi \& Frauenfelder 1996; Jakubowicz \& Rigaut 2000), Italian (Schaeffer 1997), and Spanish (Fujino \& Sano 2002), as well as bilingual Spanish in contact with Basque (Ezeizabarrena 1996; Larrañaga 2000; Larrañaga \& Guijarro-Fuentes 2011). In other languages, such as (Standard Modern) Greek (Tsakali \& Wexler 2003), Romanian (Babyonyshev \& Marin 2006), Serbo-Croatian (Ilic \& Deen 2004), and possibly Spanish (Wexler, Gavarró \& Torrens 2004; Gavarró, Torrens \& Wexler 2010), children were found not to omit clitics from age 2, but see the following discussion.

(ii) Children tend to place their clitics in the correct position from the onset of clitic production. For instance, Guasti (1993/1994) shows that Italian children place clitics preverbally in declarative sentences, but postverbally in imperative and nonfinite contexts in a targetlike way. Similar findings have been reported for other languages in which proclisis is the dominant pattern for clitic placement (e.g., Marinis 2000, for Greek; Ezeizabarrena 1996, 1997, for Spanish; Wexler, Gavarró \& Torrens 2004, for Spanish and Catalan). As for predominantly enclitic languages, such as European Portuguese and Cypriot Greek, children are known to make placement errors, generalizing the postverbal position for clitics arguably beyond age 3 and a half (see Duarte \& Matos 2000, for European Portuguese; Petinou \& Terzi 2002, for Cypriot Greek).

The data collected so far for all of these languages allow for some conclusions to be drawn regarding the nature of the problems in the acquisition of clitics. First, when children omit clitics, they do not do so because of the phonological deficiency of these forms. As shown in Jakubowicz et al. (1998), children omit accusative clitics in French but do not omit determiners with the exact same phonological form. Clitics are phonologically similar across languages, yet they are omitted only in some of the clitic languages.

Second, the rate and nature of clitic omission may be language-specific. For this reason, it is important to determine in which languages clitics are actually omitted, and at what rate. Take Spanish, for instance: while Wexler, Gavarró \& Torrens (2004) claim that there is very little or no omission of clitics in the language, Castilla, Pérez-Leroux \& Eriks-Brophy (2008) contend that there is some, although the variety of Spanish examined in the two studies is not the same; the former is a study of continental Spanish and 
the latter of Columbian Spanish. ${ }^{3}$ Similar lack of consensus on the status of omission within a language exists for Romanian (Avram 1999, 2001; Babyonyshev \& Marin 2006) and French (Jakubowicz et al. 1998; Pérez-Leroux, Pirvulescu \& Roberge 2008a). These different results-even for the same languagemay stem from the fact that the data have been collected with different methodologies or come from different sources (spontaneous speech vs. experiments). One has to be cautious about a direct comparison between languages when the methods used were not exactly the same; in other words, it is not entirely clear if one can say that languages differ with respect to the acquisition of clitics on the basis of data gathered with different methodologies.

As for object pronouns, good production has been reported in elicitation studies for English (De Villiers, Cahillane \& Altreuter 2006, but see Hyams \& Wexler 1993 and Valian 1991, for evidence from spontaneous data that there is little object omission in English before the age 4;06), Dutch (Spenader, Smits \& Hendriks 2009), and Hebrew-speaking children (Ruigendijk et al. 2010; Novogrodsky, Balaban \& Friedmann 2010), but relatively high levels of omission have been observed for German-speaking children (Jakubowicz et al. 1996, 1997; Ruigendijk et al. 2010).

For the purposes of this study, we asked the following research questions:

What is the pattern of third-person object pronominal production at the age of 5 years, when children who acquire different languages are tested with the same methodology?

In particular:

(RQ1) Are pronouns produced better than clitics or vice versa?

(RQ2) Is there a difference in clitic placement errors for languages with different clitic positions?

We will use the term pronoun to cover both weak and strong pronouns. ${ }^{4}$

This article is structured as follows. Section 2 provides the relevant background concerning existing research on clitic and pronoun production tasks with young children, followed up in section 3 by crosslinguistic issues of clitic placement, and core properties of the languages included in the study, divided into clitic languages and pronoun languages. In section 4 , the methodology of the experimental task is described in detail and results are presented in section 5. Section 6 contains the discussion of the findings.

\section{Background: clitic and pronoun elicited production studies}

Experiments eliciting production of accusative clitics have been carried out in several languages. As mentioned earlier, the results reported in the literature show a great deal of heterogeneity, across languages, but also for the same language, and even in the same age range for a given language. Most of these studies have been undertaken on 2-, 3-, 4-, and 5-year-old children. Table 1 lists elicited production experiment results by age of the children studied, by particular study and by language, including Catalan, French, Greek, Italian, Portuguese, Romanian, and Spanish. The results are summarized in three rates: rate of clitic production (including clitics produced with agreement errors); rate of object omission; and rate of production of full, lexical DPs. ${ }^{5}$

\footnotetext{
${ }^{3}$ Research by Fujino \& Sano (2002), Ezeizabarrena (1996, 1997), Larrañaga (2000), and Larrañaga \& Guijarro-Fuentes (2011) suggests that there is more omission, based on naturalistic longitudinal corpora. However, the obligatory contexts for clitic production in naturalistic data are often few or include different kinds of clitics, such as first-, second-, and third-person pronominal clitics or reflexive clitics; thus, the conclusions based on naturalistic data should be read with caution. Moreover, the (Basque Region in the North of Spain) Spanish variety of some of the children studied in Ezeizabarrena (1996, 1997), Larrañaga (2000), and Larrañaga \& Guijarro-Fuentes (2011) permits null objects in some environments (see Franco \& Landa 2003).

${ }^{4}$ Most studies for different languages have focused on third-person accusative clitics only. Little is known concerning the acquisition of other clitics and pronouns in most languages. Some exceptions are Babyonyshev \& Marin (2006) for dative clitics in Romanian, Jakubowicz \& Rigaut (2000) for reflexive clitics in French, Costa et al. (2008) for dative and reflexive clitics in all persons in European Portuguese, Ezeizabarrena (1996) for the production of first- and second-person Spanish clitics and pronouns from age 1;06 to 4, Gavarró \& Mosella (2009) for indirect object clitics in Catalan, Novogrodsky, Balaban \& Friedmann (2010) for reflexive pronouns in Hebrew, and Ruigendijk et al. (2010) for reflexive pronouns in Hebrew and German.

${ }^{5}$ Note that these three rates often do not add up to $100 \%$, as children also produced other answers irrelevant to clitic production.
} 


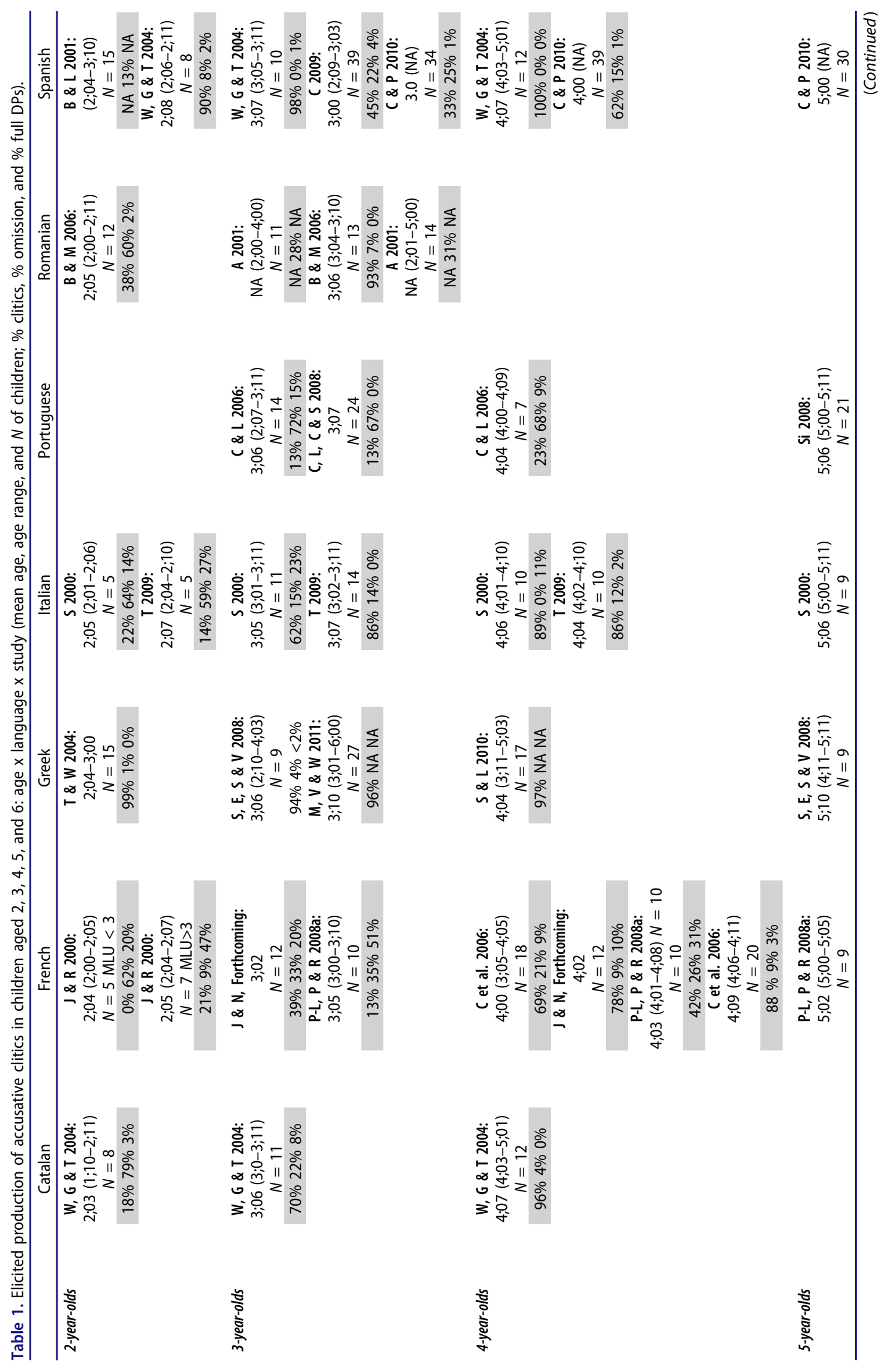




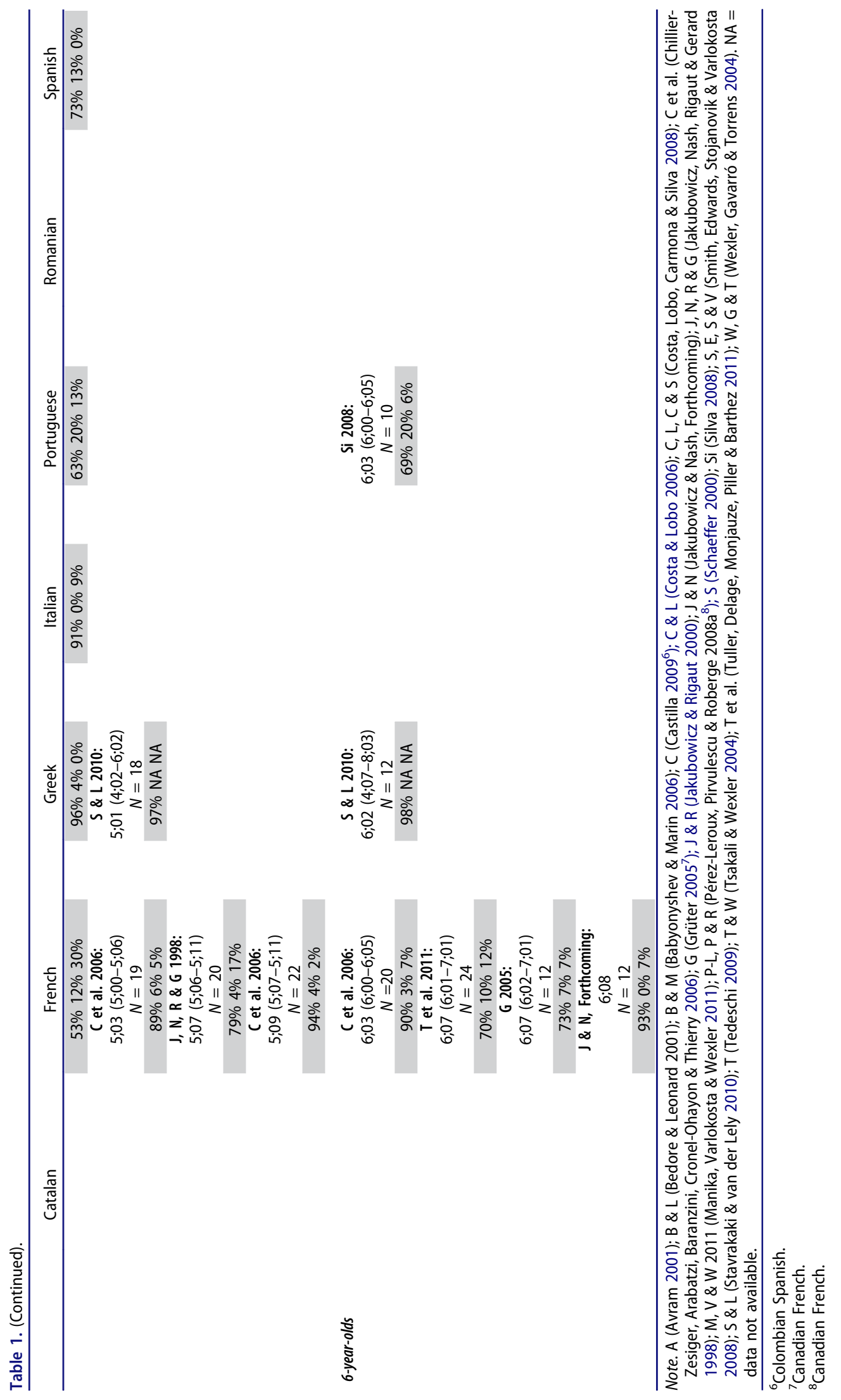


From Table 1, we see that in some languages clitic production (the first rate provided in the grey cells) is quite high from very early on (for example, in Greek); in other languages this rate is initially quite low (Catalan, French, Italian, and Romanian). Clitic production appears to remain low for some time in French and in Portuguese, though different studies show quite different rates for clitic production in French, even at age 3 and 4 . This wide variation in results for French continues in the studies of older children, ranging from just above $50 \%$ to well over $90 \%$ in 5- and 6-year-olds. Extremely varying rates of clitic production (and DP production and omission) are reported for Spanish elicited production experiments throughout the ages studied, with rates ranging from $45 \%$ to $100 \%$ in children aged 3 and 4 . While, at first glance, differences in rates might be taken to be related to differences in the dialect of the particular language under investigation (Colombian Spanish versus Iberian Spanish or Canadian French versus continental French), closer examination shows that varying rates are found for the same variety of a language, particularly for French (e.g., Jakubowicz \& Rigaut [2000] for 2-year-olds; Chillier-Zesiger et al. [2006] for 4-year olds; Chillier-Zesiger et al. [2006] vs. Tuller et al. [2011] for 6-year-olds). Notice also that the rates of clitic omission and production of a full DP also vary considerably from study to study, including studies of the same age range and the same language (Italian:Schaeffer 2000 vs. Tedeschi 2009, for 3-year-olds; Romanian: Babyonyshev \& Marin 2006 vs. Avram 2001, for 3-year-olds). Sorting out which of all these differences are genuine is extremely difficult. Not only are the SDs that accompany these means often very high (see references cited), and the number of participants in some of them very small, but, more importantly, different tasks were used.

Concerning experimental methodology, in the first studies conducted, the child was shown some pictures, and prompts used to elicited clitic production were like that exemplified in (1):

(1) What is $\mathrm{X}$ doing to/with $\mathrm{Y}$ ?

This was the method used by Jakubowicz and collaborators in various studies, by Avram (1999), and, subsequently, by Smith et al. (2008), Stavrakaki \& van der Lely (2010), and Tuller et al. (2011). In Chillier et al. (2006) and Castilla (2009) the same kind of prompt was preceded by a short story, building up to the outcome, as in (2):

(2) It's late, it's time to go to bed, there's a blanket. What is papa doing to Pierre?

Schaeffer $(1997,2000)$ modified this method and introduced a second experimenter:

(3) Experimenter 1: What's X doing?

Experimenter 2: I know what he is doing: He is verbing Y.

Experimenter 1: No, he's not. You tell us: What is $\mathrm{X}$ doing to $\mathrm{Y}$ ?

Schaeffer's method was adopted by Babyonyshev \& Marin (2004), Tsakali \& Wexler (2004), Wexler, Gavarró \& Torrens (2004), Costa \& Lobo (2006, 2007), Pérez-Leroux, Pirvulescu \& Roberge (2008a), and Manika, Varlokosta \& Wexler (2011).

Bedore \& Leonard (2001) resorted to a completion task, as exemplified in (4):

(4) Experimenter: The children wash the car and then ...

Child: [they] it-push.

All these elicitation methods share the property of focusing on the verb and rendering the object referent as part of the background knowledge. However, they differ in the degree to which the direct object referent is a well-established topic. The more salient the direct object is in the discourse, the more likely it will be pronominalized, as opposed to being produced as a full DP. On the other hand, in languages with a null object option, null objects are also more likely to occur in this kind of context. Schaeffer's method appears to have been particularly successful in eliciting pronominal answers instead of full DPs. Another feature all of these experiments have in common is the fact that they not only elicit a direct object pronoun, but they also elicit a subject pronoun. For Catalan, Greek, Italian, Portuguese, Romanian, and Spanish, which are all (subject) pro-drop languages, this simply means that the elicited answer will consist of the object clitic and 
the verb. In French, however, the elicited answer requires production of a nominative clitic followed by an accusative clitic (a clitic cluster) followed by the verb.

Further variations in the elicitation method occur as a result of other language-specific properties. Thus, Costa \& Lobo (2006) and Costa et al. (2008) added a strong island condition, for reasons that are reviewed in Section 4. These experiments differ also as to the other elements that were elicited besides definite thirdperson accusative clitics: Some experiments included items eliciting reflexive clitics, or first- or secondperson accusative clitics, and Pérez-Leroux, Pirvulescu \& Roberge (2008a) and Tedeschi (2009) included a "non-individuated" condition (with a prompt, after correction as in the Schaeffer method, of "What did X do?" eliciting an answer containing a new event "Bertrand is eating [the bone]"). Experiments with multiple conditions could be argued to increase task difficulty, as, in any given condition, the child is in the position of having to inhibit responses that are readily present due to another experimental condition being present in the task. ${ }^{9}$

Elicited production experiments specifically focused on how well children produce object pronouns are rather sparse. Jakubowicz et al. $(1996,1997)$ found that object omission is very frequent in the elicited production of German 2- and 3-year-olds with mean length of utterance (MLU) below 3 (50\% in three children with MLU < 3 in Jakubowicz et al. 1996; 55\% in seven children with MLU < 3 in Jakubowicz et al. 1997), and these omissions often result in target-deviant constructions. ${ }^{10}$ Ruigendijk et al. (2010) found also relatively high levels of object omission in an elicitation experiment using pictures ("Here the woman wets the girl down, and what does the woman do to the girl here? [she] dries/towels her") with German-speaking $3-, 4-, 5-$, and 6-year-olds (omission rates of $23 \%, 9 \%, 7 \%$, and $10 \%$ respectively, and pronouns produced at $40 \%, 55 \%, 76 \%$, and $58 \%$, and DPs at $3 \%, 13 \%, 9 \%$, and $24 \%$ ). These results for German pronouns are in contrast with studies on pronoun production of English-, Hebrew-, and Dutch-speaking children. De Villiers, Cahillane \& Altreuter (2006) observed nearly flawless production of pronouns, in their elicited production study, with English-speaking children between 4;06 and 7;02 years old (mean age 6;03). ${ }^{11}$ Similarly, in their elicited production experiment, Ruigendijk et al. (2010) and Novogrodsky, Balaban \& Friedmann (2010) found that Hebrew-speaking children produced very few omissions $(4 \%, 13 \%, 2 \%, 4 \%$, and $4 \%$ in 2-, 3-, 4-, 5-, and 6-year-olds respectively) and pronouns were produced at rates of $70 \%$ for the 2and 3-year-olds, and $87 \%-92 \%$ for the 4 - to 6-year-olds (while DPs were generally marginal-3\%-7\%). Finally, Spenader, Smits \& Hendriks (2009) report that Dutch-speaking children aged 4;05 to 6;06 (mean age 5;05) exhibited flawless pronoun production, as they rarely produced reflexives instead of pronouns in the conditions that targeted a pronoun response (the focus of this study was on the difference between pronouns and reflexives). However, it is worth noting that in some of these conditions children produced a high proportion of full DPs rather than pronouns. This choice was natural because their contexts presented two equally focused antecedents, and so using a pronoun would in fact be confusing. Table 2 illustrates the elicited production data from studies that provided details (Jakubowicz et al. 1996; Ruigendijk et al. 2010; Spenader, Smits \& Hendriks 2009).

To sum up, studies of elicited production of accusative clitics with 2- to 6-year-old children show a great deal of heterogeneity, in methodology and in results, across languages and within languages. Overall, it has been reported that accusative clitic production is quite high in some languages from very early on (for example, in Greek), while in other languages this rate is at least initially quite low (for example, in Catalan, French, and Italian). Studies of elicited pronoun production are quite few in number, and their results are

\footnotetext{
${ }^{9}$ Further discrepancies in the results are found in the studies using repetition (Eisenchlas 2003) or based in spontaneous production, in which the criteria for determining when a clitic should be expected vary from study to study (see the results in Guasti 1993/94; Lyczkowski 1999; Fujino \& Sano 2002; Gavarró, Mata \& Ribera 2006; Pirvulescu 2006, etc).

${ }^{10}$ Similar conclusions are reached by Jakubowicz et al. $(1996,1997)$ on the basis of spontaneous language samples, as well.

${ }^{11}$ Although Hyams \& Wexler (1993) and Valian (1991) report object omission in English before the age 4;06 (between 1;01 to 2;08 years [Valian 1991]; between 1;06 to 3;00 years [Hyams \& Wexler 1993]) on the basis of spontaneous data, both studies find that the level of object omission is not high compared to the level of subject omission observed in the same period. For example, in Hyams \& Wexler (1993), the proportion of missing subjects in Adam's (between 2;05 to 3;00 years) and Eve's (between 1;06 to $2 ; 01$ years) speech is $48 \%$, compared to $8 \%$ of missing objects in the early period, and $22 \%$ compared to $8 \%$ respectively in the late period.
} 
Table 2. Elicited production of object pronouns in children aged 2, 3, 4, 5, and 6: Age x language $\mathrm{x}$ study (mean age, age range, and $N$ of children; \% pronouns, $\%$ omission, and $\%$ full DPs).

\begin{tabular}{|c|c|c|c|}
\hline & Dutch & German & Hebrew \\
\hline 2-year-olds & & $\begin{array}{c}\text { J et al. 1996: } \\
2 ; 09(2 ; 05-3 ; 01) \\
N=3, M L U<3 \\
5 \% 50 \% 45 \% \\
2 ; 06(2 ; 06-2 ; 09) \\
N=3, M L U>3 \\
55 \% 15 \% 30 \%\end{array}$ & $\begin{array}{c}\text { R et al. 2010: } \\
2 ; 08(2 ; 04-2 ; 11) \\
N=7 \\
70 \% 4 \% 7 \%\end{array}$ \\
\hline 3-year-olds & & $\begin{array}{c}\text { R et al. 2010: } \\
3 ; 06(3 ; 01-3 ; 09) \\
N=12 \\
40 \% 23 \% 3 \%\end{array}$ & $\begin{array}{c}\text { R et al. } 2010: \\
3 ; 05(3 ; 01-3 ; 09) \\
N=14 \\
70 \% 13 \% 4 \%\end{array}$ \\
\hline 4-year-olds & & $\begin{array}{c}\text { R et al. 2010: } \\
4 ; 06(4 ; 01-4 ; 11) \\
N=11 \\
55 \% 9 \% 13 \%\end{array}$ & $\begin{array}{c}\text { R et al. } 2010: \\
4 ; 05(4 ; 00-4 ; 10) \\
N=15 \\
87 \% 2 \% 4 \%\end{array}$ \\
\hline 5-year-olds & $\begin{array}{c}\text { S et al. } 2009 \\
5 ; 05(4 ; 05-6 ; 06) \\
N=83^{*} \\
34 \% \text { NA\% } 38 \%\end{array}$ & $\begin{array}{c}\text { R et al. 2010: } \\
5 ; 06(5 ; 01-5 ; 11) \\
N=11 \\
76 \% 7 \% 9 \%\end{array}$ & $\begin{array}{c}\text { R et al. } 2010: \\
5 ; 06(5 ; 03-5 ; 10) \\
N=14 \\
89 \% 4 \% 5 \%\end{array}$ \\
\hline 6-year-olds & & $\begin{array}{c}\text { R et al. 2010: } \\
6 ; 04(6 ; 01-6 ; 08) N=10 \\
N=10 \\
58 \% 10 \% 24 \%\end{array}$ & $\begin{array}{c}\text { R et al. 2010: } \\
6 ; 04(6 ; 02-6 ; 07) N=10 \\
N=10 \\
91 \% 3 \% 4 \%\end{array}$ \\
\hline
\end{tabular}

Note. R et al. (Ruigendijk, Friedmann, Novogrodsky \& Balaban 2010); S et al. (Spenader, Smits \& Hendriks 2009); J et al. (Jakubowicz, Müller, Kang, Riemer \& Rigaut 1996); NA = data not available.

*Data for different age groups are not available.

often inconsistent: High rates of object omission are observed in some of them, while very few omissions are reported in others.

\section{Summary of the salient distributional properties of pronominals in clitic and pronoun languages}

In this section, we list some of the most salient distributional properties of the pronominal systems of the languages tested in our cross-linguistic experiment.

Clitic languages are those languages that have clitic pronouns in addition to (strong and/or weak) pronouns. The 11 clitic languages in our sample are Cypriot and (Standard Modern) Greek; six Romance languages: Catalan, (European) Portuguese, French, Italian, Romanian, and Spanish; and three Slavic languages: Croatian, Polish, and Serbian. We will only discuss third-person accusative clitics/pronouns, as these are relevant for the elicitation task we have created.

In all Romance languages and in (Cypriot) Greek, third-person clitics are usually homophonous to definite determiners. Third-person singular clitics inflect for gender, number, and case. Regarding placement, proclisis is generally observed with finite verbs and enclisis with nonfinite ones and with affirmative imperative. Exceptions are Portuguese and Cypriot Greek, where proclisis is syntactically determined. In French, proclisis is also observed with nonfinite verbs. With negative imperative, proclisis or enclisis is observed, depending on the verbal form used to express the imperative; in Italian, infinitives are used and both enclisis and proclisis are possible; in Catalan and Spanish, the subjunctive is used and proclisis is evident; in French, the clitic is proclitic in negative imperative (featuring the same order as with infinitives); in Romanian, clitics are preverbal in infinitival structures introduced by $a$, and the clitic $o$ is pre- or postverbal depending on the verb form. In Italian, French, and Catalan, a clitic preceding the past participle triggers participle agreement (agreement is not always audible in French or used when audible). In addition to clitics, null objects are allowed in Portuguese, but these are not possible in island contexts, like adverbial 
clauses. Some instances of null objects are observed in French, but no island restriction applies in this case, and these instances of null objects appear to be lexically determined. Null objects are also allowed in some environments (i.e., for inanimate objects) in Basque Spanish (see Franco \& Landa 2003). In Catalan, Portuguese, Italian, and Spanish, clitic climbing is (optionally) observed with auxiliaries and restructuring verbs. Romanian (and some varieties of Spanish) have clitic doubling, and finally, in Portuguese, mesoclisis (with future and conditional) is found (for clitics in [Cypriot] Greek, see Agouraki 1997; Anagnostopoulou 1994; Terzi 1999; for clitics in the Romance languages, see Belletti 1999; Kayne 1991; Sportiche 1996; Uriagereka 1995). In Slavic languages, like Croatian and Serbian, clitics occur in second position, and enclitic placement is typical. In Polish, clitics tend to occur in second position, but they can be placed at different positions as well, due to the relatively free word order of the language; clitics are canonically enclitics, but there is a tendency to find them in different positions (e.g., as proclitics) (for clitics in the Slavic languages, see Bošković 2001; Browne 1974; Dimitrova-Vulchanova 1999, Franks 2010; Franks \& King 2000).

The five pronoun languages in our sample include four Germanic languages: German, Dutch, Danish, and English; and the Semitic language Hebrew (see for Germanic languages, Cardinaletti 1999, Cardinaletti \& Starke 1999; Laenzlinger \& Shlonsky 1997; Schaeffer 2000; Zwart 1991; for Hebrew, Friedmann 2007). All of these languages have strong and weak pronouns, where the difference is mainly in terms of presence versus absence of stress. Pronouns generally inflect for gender, number, and case. They are typically positioned where full DPs appear. ${ }^{12}$ In Dutch and German, pronouns scramble, while this process is more restricted for full DPs. Thus, in Dutch main clauses, pronouns appear right-adjacent to the finite verb in verb-second position, and in embedded clauses, they appear right-adjacent to the subject. In German, pronouns in embedded clauses appear after the complementizer (second position or Wackernagel position), ${ }^{13}$ while in main clauses they are not necessarily adjacent to the verb in the second position.

\section{Methodology}

\subsection{Participants}

The participants were children with no diagnosed language, hearing, or speech pathologies. All participants were monolingual native speakers of the language they were tested in. Generally, 20 children were tested for each language. The number of children, their ages, and their genders are presented for each language in Table 3. We tested kindergarten and preschool children aged 5;00-5;11.

Table 3. Participants' information per language.

\begin{tabular}{|c|c|c|c|c|c|c|}
\hline Language & $\mathrm{N}$ & Age range (months) & Mean age (months) & SD age (months) & Girls & Boys \\
\hline Catalan & 20 & $61-70$ & 65 & 3 & 10 & 10 \\
\hline Croatian & 25 & $60-70$ & 63 & 3 & 12 & 13 \\
\hline Cypriot Greek & 24 & $60-72$ & 67 & 4 & 13 & 11 \\
\hline Danish & 23 & $59-62$ & 64 & 5 & 13 & 10 \\
\hline Dutch & 20 & $61-72$ & 67 & 4 & 12 & 8 \\
\hline English & 19 & $63-71$ & 67 & 3 & 11 & 8 \\
\hline French & 25 & $62-70$ & 66 & 3 & 13 & 12 \\
\hline German & 22 & $59-69$ & 64 & 3 & 11 & 11 \\
\hline Greek & 20 & $60-71$ & 65 & 4 & 11 & 9 \\
\hline Hebrew & 21 & $59-71$ & 64 & 4 & 8 & 13 \\
\hline Italian & 20 & $61-71$ & 67 & 4 & 6 & 14 \\
\hline Polish & 31 & $61-71$ & 68 & 3 & 15 & 16 \\
\hline Portuguese & 20 & $60-71$ & 66 & 3 & 13 & 7 \\
\hline Romanian & 20 & $61-72$ & 65 & 3 & 11 & 9 \\
\hline Serbian & 25 & $60-71$ & 67 & 3 & 10 & 15 \\
\hline Spanish & 23 & $60-68$ & 64 & 2 & 12 & 11 \\
\hline
\end{tabular}

\footnotetext{
${ }^{12}$ In Hebrew there are certain distributional differences between pronouns and full DPs. Specifically, unlike full DPs, pronouns cannot appear postverbally after an unaccusative verb (Friedmann 2007).

${ }^{13}$ It is actually weak/unstressed pronouns that appear after the complementizer in embedded clauses (Müller 2001; Grohmann 1997; Laenzlinger \& Shlonsky 1997).
} 


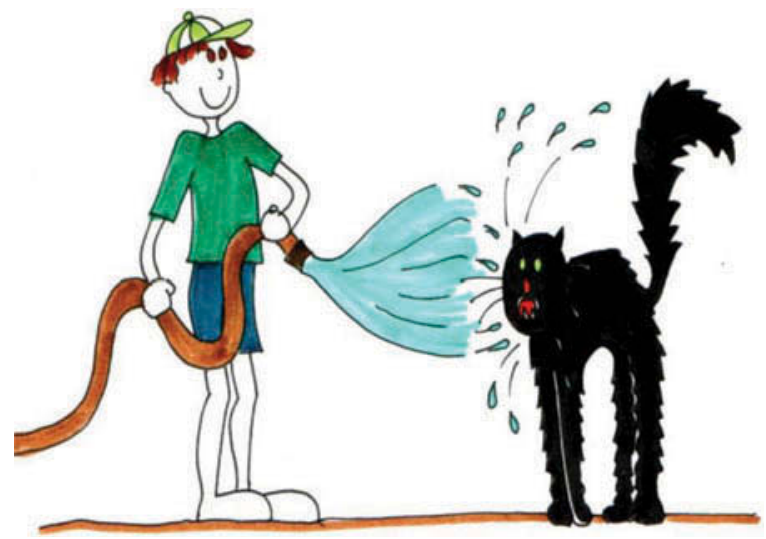

Figure 1. Sample test picture.

In order to establish what the target situation was, we also tested adult native controls in each language: Catalan (27 adults), Croatian (10 adults), Cypriot Greek (8 adults), Danish (8 adults), Dutch (15 adults), English (5 adults), French (10 adults), German (8 adults), Greek (10 adults), Hebrew (10 adults), Italian (13 adults), Polish (12 adults), Portuguese (10 adults), Romanian (12 adults), Serbian (10 adults), and Spanish (20 adults). This was particularly necessary for the languages in which the use of pronominals may be complicated by the presence of some other option (e.g., null objects are an option in European Portuguese or in French, although under different conditions).

\subsection{Task and procedure}

To elicit object pronominals, we used a picture and a question that triggered a reply with a because-clause containing a pronominal. The context strongly favors the use of a pronominal by making the antecedent very salient in the discourse. First, a picture was presented in which one animate character was performing an action on another character or object. The experimenter described the picture in a sentence and then asked the child a why-question. For example, for Figure 1, the experimenter's introduction and the target sentence are given in (5). The corresponding introductions and target clauses for this test item are provided for all languages in Appendix A.

(5) Experimenter: "The boy is spraying the cat and the cat is wet. Why is the cat so wet? The cat is wet..." Target response: “... because the boy is spraying him."

The use of the because-clause was motivated by one of the tested languages, Portuguese, which allows for null objects but not inside syntactic islands. To create a context in which a pronominal is required (and a null object is ungrammatical)—even in Portuguese-we employed a strong island, introduced by because. In such a context, according to Raposo (1986) and Costa \& Lobo (2006), null objects are ruled out; see example (6) from Costa \& Lobo (2006).

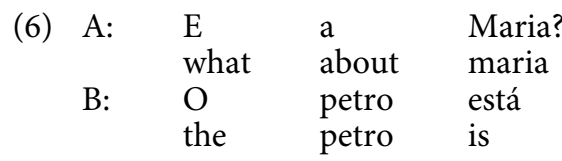

$\begin{array}{llllll}\text { triste } & \text { porque } & \text { o } & \text { zé } & *(a) & \text { beijou. } \\ \text { sad } & \text { because } & \text { the } & \text { zé } & \text { her }_{\mathrm{CL}} & \text { kissed }\end{array}$

The test started with two training items, which targeted object clitics or pronouns. Clitics or pronouns were provided by the experimenter if the child did not produce them. No further feedback was provided once the experimental session started. 
Each participant was tested individually in a quiet room in the kindergarten/school or at home. No time limit was imposed during testing, and no response-contingent feedback was given by the experimenter, only general encouragement. The sessions were tape-recorded and transcribed in full during the testing as well as after the test, by native speakers.

\subsection{Materials}

One of the most challenging tasks was to find a list of strongly transitive verbs that suited all the languages studied and that could be used in sentences with direct objects. We specifically chose verbs for which transitivity was not lost in the translation/adaptation across languages. The list of the verbs used, short descriptions of the pictures, and the lead-in sentences for the English experiment are presented in Appendix B. The list of the verbs used in the 16 languages are listed in Appendix C.

The target sentences included singular pronouns of various genders (feminine, masculine, and neuter, where applicable). Our pilot studies revealed that the gender of the target pronominal element did not have any effect on clitic/pronoun production, and thus we decided not to balance for gender in the final testing, as this would have been very difficult, since gender is very idiosyncratic across languages.

The pictures were controlled for cultural appropriateness. Before final testing, several pilot studies were run to ensure that the pictures were clear and the verbs were appropriate. After piloting, we changed some pictures and verbs that had elicited nontarget responses in some of the languages, typically indirect objects and descriptions that did not use the target verb.

The test included 12 test sentences and five fillers. The fillers targeted sentences without object pronouns.

\subsection{Scoring}

In clitic languages, we expected children to produce clitics, and in pronoun languages, we anticipated use of pronouns (strong or weak). We did not distinguish between weak and strong pronouns, as it was rather difficult to distinguish them consistently across different languages; thus, weak and strong pronouns are collapsed together in the scoring. Alternative responses found in the data were categorized in the following categories: use of the corresponding full noun phrase (DP), failure to produce any direct object (i.e., omission), use of pronouns in clitic languages, and production of other responses.

We also scored errors of gender, number, and case. Sometimes participants changed the target verb but employed a verb that still required a direct object. These were not counted as errors as long as a clitic was produced in a clitic language or a pronoun in a pronoun language.

\section{Results}

Responses were analyzed both in a quantitative and a qualitative way. Tables 4 and 5 provide the mean percentages of scores in the clitic and pronoun languages respectively for the native adult control data. The data in Tables 4 and 5 establish what the target situation was in each of the languages tested.

Tables 6 and 7 provide the mean percentages of scores in the clitic and pronoun languages respectively for the child data. Our test prompted production of pronominals, as the relevant referent was already mentioned in the previous discourse. As discussed earlier, pronominals take different forms in various languages: clitics, weak or strong pronouns. In general, the most deficient pronominal form of a language is used, unless the context requires otherwise. This means that, in a language with clitics, these must be employed in situations like the one created by our task, while the use of pronouns would not be appropriate. In German, English, or Dutch, however, pronouns are expected to be employed, as these languages do not have clitics. Therefore, our first analysis aimed at establishing whether children used the target pronominal form in their language and whether they did so to the same extent in all languages 
Table 4. Mean percentages of use of clitics, DPs, omission, pronouns, and other structures in clitic languages (adult data).

\begin{tabular}{lccccc}
\hline Language & Clitics & DPs & Omission & Pronouns & Other \\
\hline Catalan & 99.7 & 0 & 0 & 0 & 0.3 \\
Croatian & 90.2 & 2.3 & 6.0 & 0 & 1.5 \\
Cypriot Greek & 100.0 & 0 & 0 & 0 & 0 \\
French & 93.3 & 6.7 & 0 & 0 & 0 \\
Greek & 98.4 & 0 & 0 & 0 & 1.6 \\
Italian & 91.0 & 0 & 0 & 0 & 9.0 \\
Polish & 84.0 & 14.6 & 0 & 0 & 1.4 \\
Portuguese & 88.3 & 1.7 & 3.3 & 0 & 6.7 \\
Romanian & 96.5 & 0 & 0 & 0 & 3.5 \\
Serbian & 97.5 & 2.5 & 0 & 0 & 0 \\
Spanish & 93.3 & 2.1 & 0 & 0 & 4.6 \\
\hline
\end{tabular}

Table 5. Mean percentages of use of pronouns, DPs, omission, and other structures in pronoun languages (adult data).

\begin{tabular}{lcccc}
\hline Language & Pronouns & DPs & Omission & Other \\
\hline Danish & 88.5 & 9.5 & 0 & 2.0 \\
Dutch & 89.0 & 10.0 & 0 & 1.0 \\
English & 95.0 & 5.0 & 0 & 0 \\
German & 92.7 & 2.1 & 1.0 & 4.2 \\
Hebrew & 98.4 & 0.8 & 0 & 0.8 \\
\hline
\end{tabular}

Table 6. Mean percentages of use of clitics, DPs, omission, pronouns, and other structures in clitic languages (child data).

\begin{tabular}{llcccc}
\hline Language & Clitics (range; SD) & DPs & Omission & Pronouns & Other \\
\hline Catalan & $98.8(92.0-100 ; 3)$ & 0.4 & 0.0 & 0.0 & 0.8 \\
Croatian & $79.6(33.0-100 ; 18)$ & 5.0 & 6.4 & 1.0 & 7.7 \\
Cypriot Greek & $96.0(83.0-100 ; 5)$ & 0.7 & 0.6 & 0.0 & 2.7 \\
French & $90.0(33.0-100 ; 19)$ & 4.7 & 2.3 & 4.2 & 3.0 \\
Greek & $92.1(67.0-100 ; 10)$ & 2.5 & 0.4 & 0.8 & 0.8 \\
Italian & $92.9(67.0-100 ; 10)$ & 2.5 & 2.5 & 3.0 & 1.3 \\
Polish & $71.0(0.0-100 ; 33)$ & 3.0 & 18.3 & 8.2 & 4.8 \\
Portuguese & $19.3(0.0-75 ; 25)$ & 11.9 & 56.1 & 0.0 & 4.5 \\
Romanian & $90.8(67.0-100 ; 11)$ & 5.4 & 6.3 & 2.7 & 2.5 \\
Serbian & $77.7(42.0-100 ; 14)$ & 6.3 & 6.7 & 1.1 & 6.6 \\
Spanish & $94.2(75.0-100 ; 7)$ & 1.8 & 2.2 & & 0.7 \\
\hline
\end{tabular}

Table 7. Mean percentages of use of pronouns, DPs, omission, and other structures in pronoun languages (child data).

\begin{tabular}{lcrrr}
\hline Language & Pronouns (range; SD) & DPs & Omission & Other \\
\hline Danish & $70.0(0.0-100 ; 30)$ & 12.6 & 2.5 & 14.9 \\
Dutch & $66.2(8.0-83.0 ; 25)$ & 8.8 & 20.0 & 5.0 \\
English & $81.6(25.0-100 ; 23)$ & 18.0 & 0.0 & 0.4 \\
German & $89.0(67.0-100 ; 11)$ & 4.6 & 3.4 & 3.0 \\
Hebrew & $98.9(92.0-100 ; 2)$ & 0.4 & 0.0 & 0.7 \\
\hline
\end{tabular}

investigated. This means that, in clitic languages, clitics were the target form; in languages without clitics, weak or strong pronouns were the target form, as indicated by the adult native control data in Tables 4 and 5 respectively.

To investigate the potentially different percentages of use for clitics versus pronouns, a $t$-test was conducted comparing all clitic versus all pronoun languages. No significant difference was observed, $t(357)=0.85, p=.30$. The same percentage of pronominals was used in pronoun languages $(M=81$, $S D=24)$ and in clitic languages $(M=84, S D=25)$. Thus, it is evident that children at this age use the appropriate pronominal form at a high level.

We next compared the use of clitics among clitic languages with a one-way ANOVA with languages as the independent variable and percentage of clitics as the dependent variable. This revealed a significant difference, $F(10,242)=33.68, p<.001$, with further analysis, using a post hoc Scheffé test revealed that 
the use of clitics is significantly lower in Portuguese than in all the other languages, and it is lower in Polish than in Catalan, Cypriot Greek, Italian, and Spanish $(p<.001)$. Table 6 displays the mean percentages as well as the ranges and SDs of clitic use in the clitic languages. It also reports the mean percentages of use of DPs, omission, pronouns, and other structures.

In Portuguese, children mostly used null elements, some DPs, and pronouns. An ANOVA with percentage of null elements as the dependent variable displays a significant difference among clitic languages, $F(10,242)=29.76, p<.001$; a post hoc Scheffé test reveals that Portuguese is different from all the other languages $(p<.001)$, and Polish is also different from Catalan, Cypriot Greek, French, and Greek $(p<.05)$. A second ANOVA with percentage of DPs as the dependent variable reveals a significant effect of language, $F(10,242)=2.94, p<.01$, due to Portuguese differing from Catalan, Cypriot Greek, and Spanish in the use of DPs $(p<.05)$. Then, we compared the use of clitics in adult and child Portuguese and found that adults use more clitics than children $(M=88, S D=7$ for adults and $M=19.3, S D=25$ for children), as confirmed by an ANOVA with percentage of use of clitics as the dependent variable, $F(1,28)=$ $69.45, p<.001$. No difference was found in the use of clitics between children and adults in French $(M=90$, $S D=16$ for children and $M=93, S D=10$ for adults $)$ and in Polish $(M=84, S D=29$ for adults and $M=71$, $S D=33$ for children).

All children produced at least one clitic, except 9/20 children in Portuguese and 2/31 children in Polish, who did not produce clitics at all. In most of the clitic languages, at least half of the children produced 100\% clitics: 11/20 children in Catalan, 14/24 in Cypriot Greek, 9/25 in French, 10/20 in Greek, 11/20 in Italian, 9/20 in Romanian, and 15/23 in Spanish. In Polish, Croatian, and Serbian, only $3 / 31,5 / 25$, and $3 / 25$ children respectively produced $100 \%$ clitics.

Errors of gender, number, and case are very rare but are found in all languages except Cypriot Greek. Their percentages range from $0 \%$ to $12 \%$ errors at most, calculated on the number of clitics used. An ANOVA with percentages of errors in clitic languages as the dependent variable yields a significant effect of language, $F(10,242)=8.7, p<.001$, and a post hoc Scheffé test revealed that Greek has a significantly higher occurrence of errors than all other languages $(p<.05)$, except Serbian (for Greek see Varlokosta, Konstantzou \& Nerantzini 2014). Errors in the placement of clitics were found in Croatian (1.2\%), Cypriot Greek (49\%), ${ }^{14}$ and Portuguese (72\%).

Table 7 displays the mean percentages of use of pronouns, DPs, omission, and other structures in pronoun languages. The use of pronouns in pronoun languages was also not uniform, with Danish and Dutch displaying the lowest use. A one-way ANOVA on the percentage of pronoun use confirmed this observation, $F(4,101)=8.48, p=.001$, with Dutch differing significantly from German $(p=.02)$ and Hebrew $(p<.001)$, and Danish differing from Hebrew $(p<.001)$. When children did not use pronouns, they used DPs, especially in English, as shown by the ANOVA of the percentage of use of DPs, $F(4,101)=$ $3.50, p=.01$. This variation among languages in the use of DPs is essentially due to English being significantly different from Hebrew $(p=.02)$. Occasionally, children omitted pronouns altogether, especially in Dutch. In this case, the ANOVA with pronoun omission as the dependent variable yielded a significant difference, $F(4,101)=12.61, p<.001$, as Dutch differs from all the other languages $(p<.001)$. In Dutch, some instances of omission of pronouns were grammatical in the adult language, as some verbs are optionally transitive (kammen 'comb,' verven 'paint,' and likken 'lick,' as reported in van Hout, Veenstra \& Berends 2011). However, the removal of these grammatical omissions, with the percentage of ungrammatical omissions dropping from $20 \%$ to $12.5 \%$, does not affect the results, $F(4,101)=7.5, p<.001$, and Dutch is still significantly different from the other languages $(p<.01){ }^{15}$

\footnotetext{
${ }^{14}$ For further discussion of enclitic Cypriot Greek, in particular the diglossic situation in Cyprus and the differences in placement to proclitic Standard Modern Greek, see Grohmann (2011). As more comprehensive testing with younger and older children showed (Grohmann et al. 2012), the nontarget proclitic placement is not misplacement as such, but rather a reflex of the complex sociolinguistic situation. This is approached under the umbrella term of "socio-syntax of development" through competing motivations between Cypriot and Standard Modern Greek with the onset of schooling by Grohmann \& Leivada (2012).

${ }^{15}$ van Hout, Veenstra \& Berends (2011) analyzed the Dutch omission data in more detail. A subject analysis shows that there was quite some individual variation. About half of the participants did not omit objects or omitted them only once, whereas four participants omitted objects at high rates. The authors do not have any further linguistic information about these four participants.
} 
The number of children who produced $100 \%$ pronouns was high in Hebrew (19/21 children) but lower in German (9/22), English (6/19), and Danish (5/23). All children produced pronouns, except one child in Danish, who did not produce any, and two children in Dutch, who had a very low pronoun production rate $(8 \%)$.

Errors of gender, number, and case were also found, with differences among languages, mostly in German. Their percentage ranges from $0 \%$ to $19 \%$ errors at most, calculated on the number of pronoun uses. The ANOVA with percentage of errors as the dependent variable yielded a significant difference, $F(4,101)=23.81, p<.001$, due to German, which differed from all the other languages (post hoc Scheffé test $p<.001) .{ }^{16}$ Errors in the placement of pronouns were rare and were observed only in Dutch (2.5\%).

Given that there was some variation in the use of clitics among some clitic languages and in the use of pronouns among some pronoun languages, we conducted an ANOVA with verb type as independent variable and clitic/pronoun (production) as dependent variable to see whether there are differences in the production of clitics/pronouns depending on the verb used, and if there are, whether they are the same cross-linguistically. In this analysis we included only languages in which the production of clitics/pronouns was less than 90\% (Croatian, Danish, Dutch, English, German, Polish, Portuguese, and Serbian). The analysis indicated no effect of verb type, $F(11,72)=.236, p=.994$. By looking at the data, one may notice that the verb paint elicited less clitic and pronoun production in Polish and Danish respectively, the verb eat elicited less clitic production in Serbian, and the verb comb elicited less pronoun production in Dutch. Crucially, though, none of these verbs elicited less clitic/pronoun production in the other languages, as indicated by the statistical analysis.

In summary, the target pronominal form is used frequently by children. In Portuguese clitics are used only half of the time; Portuguese-speaking children mostly use null elements. Differences are observed also among pronoun languages, with Danish- and Dutch-speaking children using fewer pronouns than children speaking other languages. In Dutch, a relatively high use of null elements was observed, while in Danish a range of structures were used, mostly DPs, but their use was not significantly different. Errors of gender, number, and case were rare, and were mostly found in Polish and German. Errors in the placement of clitics were frequently observed in Cypriot Greek (but see fn. 8) and Portuguese, while the placement of pronouns was less problematic, with some rare errors found only in Dutch.

\section{Discussion}

The results of the production experiment across 16 languages reveal some general common tendencies and also a few cross-linguistic differences. First, it is clear that at the age tested, children are able to produce pronominal elements. This is evident by the high rates of clitics and pronouns produced according to the target in all languages. This massive production of pronominals is revealing in three ways:

(i) It shows that there is a general cross-linguistic consistency in the results, in the sense that it is possible to say that, at age 5 , children are able to produce pronominals in all the languages tested.

(ii) It shows that children have the relevant morphosyntactic knowledge involved in the production of pronominals; children know the placement and distribution of pronominals, and most of the time opt for the target case form.

(iii) It shows that children have the relevant pragmatic knowledge required to select a pronominal in the discourse setting involved in the experiment; this is shown by the fact that children do not freely vary between pronominals and DPs or forms that would be pragmatically infelicitous.

\footnotetext{
${ }^{16}$ Some of the gender errors in German were also observed in the adult data and were due to the mismatch between grammatical and semantic gender in the noun girl (grammatical: neuter; semantic: feminine) in the test sentences with the verbs comb and draw.
} 
In general then, it is legitimate to say that, at age 5, pronominal elements are acquired across languages.

However, some cross-linguistic differences were found, as well. Pronominals were produced in all languages but at different rates. The different rates make it possible to establish three language groups: languages with clitics, languages with strong/weak pronouns, and languages with null objects. Clitic and pronoun languages are those in which pronominals are produced at high and similar rates. In Portuguese, which has null objects, the rate of clitic production is quite low, and null complements are the preferred option. Two main observations can be drawn from these cross-linguistic differences:

(i) No difference was found between clitics and pronouns in production. This contrasts with the literature on pronominal comprehension in which a difference has been established between clitics and pronouns (see the Delay of Principle B Effect or the Pronoun Interpretation Problem; e.g., McKee 1992; Baauw, Coopmans \& Philip 1999; Baauw et al. 2011; Varlokosta 2000, among others) (nevertheless, see the discussions in Baauw et al. 2011 and Conroy et al. 2009 for the possibility that experimental design and choice of experimental materials and tasks may have affected the results observed in the comprehension studies of pronominals).

(ii) The fact that null objects are preferred in Portuguese confirms that, in this language, children overuse the weakest form of the nominal hierarchy (i.e., null objects), producing them even in a context in which the target grammar rules them out (Costa, Lobo \& Silva 2009). However, it is worth emphasizing that there does not seem to be a problem with pronominals in this language-they are produced correctly at a moderate rate. The only problem is the preference for an alternative strategy that is available in the language-the null object option. $^{17}$

The comparison between the three language groups, including the observation that, in Portuguese, children prefer the null-complement option, reveals a striking cross-linguistic pattern in spite of the differences: Across languages, children consistently opt for the weakest form available to them in the language they are acquiring. This is particularly clear in a language like Italian, which has strong, weak, and clitic pronouns, and yet children go for the weakest clitic form, or in a language like Portuguese, which has strong and clitic pronouns and null objects, and children opt for the latter. This cross-linguistic preference for the weakest form is interesting, since it again reveals that children know the relevant pragmatics associated with the discourse context and that behavior is very consistent across languages. The option for the weakest form is a sign of good pragmatic knowledge, because it indicates that children know that given referents are best mapped onto nonsalient expressions (Ariel 1990; Gundel, Hedberg \& Zacharski 1993). The cross-linguistically consistent behavior reveals not only that the differences found are superficial but also that children exhibit good knowledge of the pronominal paradigms in their languages and of the set of alternatives that could be used in the context of a pronominal. Note that, in order to select the weakest form (including the null object in Portuguese), one must accept that this form competes with the stronger alternatives. Moreover, note that our claim that children opt for the weakest form available in the language they are acquiring entails that we expect cross-linguistic variation in the forms used by children across languages, as indicated by the results of the experiment we report here.

Related to the point just made that children know the paradigms in their languages, it is interesting to comment on their knowledge about null alternatives. Tuller (2000) and Cummins \& Roberge (2005) show that French has null complements. Null objects in French, however, appear to be different from those available in Portuguese. In French, null objects are lexically constrained and not licensed in the pragmatic context of the present test. Interestingly, French children did not opt for a null complement in the context of this experiment. This indicates that children know the pragmatics associated with the empty categories available to them, as well as the lexically determined limitations of their distribution, whenever this is

\footnotetext{
${ }^{17}$ Children acquiring Portuguese are not adultlike. According to Costa \& Lobo (2011), this may be due to the fact that a late acquisition of the properties distinguishing pro and variables delays a steady knowledge of the context in which null objects are ruled out. If the null object is not interpreted like a variable, it can be used in contexts in which pronominals are accepted, such as islands.
} 
relevant, as in French. They may fail to master the syntactic distribution of the null complement, as evidenced by the overuse of null objects in strong islands by Portuguese-speaking children, but they do not randomly replace obligatory pronominals by any available null expression in the language. Again, this leads to the conclusion that their pragmatic knowledge is highly accurate at age 5.

Topic-drop is another construction that may license a null complement. In topic-drop, the empty complement must be in sentence-initial position, which does not happen in the context of elicitation of the present experiment, since we used embedded adverbial subordinate clauses. The fact that, in Dutch, there were some instances of null complements may signal that Dutch children occasionally overuse the topicdrop construction, in the same way Portuguese-speaking children overuse the null object construction.

In short, the comparison between the three types of null-complement possibilities (lexically restricted, as in French; null object, as in Portuguese; topic-drop, as in Dutch) suggests that children know the specific properties of the null complements available in their languages but may still overuse them in inadequate syntactic contexts, although not in inadequate pragmatic contexts, which explains the good performance of the French children.

Summarizing, in this discussion we provided arguments that: (i) 5-year-old children's knowledge of pronominals is target-consistent across languages; (ii) children consistently opt for the weakest alternative, in accordance to the scale pronoun > clitic $>$ null, depending on what is available in their languages; ${ }^{18}$ (iii) children reveal a very accurate knowledge of the alternative options for the discourse setting of the experiment; (iv) the preference for the weakest form in languages with a null complement may disguise the fact that children are quite competent in producing pronominals; (v) children's knowledge of null-complement typologies is good, although they sometimes misuse them extending null complements to inappropriate syntactic environments.

We have been able to reach these conclusions through use of a common methodology in 16 languages. Our method involved use of a single task that did not produce any noise. The task was short, eliciting a specific construction and not a variety of structures, thus freeing the child from possible task-related processing difficulties, and at the same time allowing us to tap into their knowledge more directly.

The overall results and the clarifications made regarding the nature of null complements-in particular the clarification that the production of null complements does not mean that children do not know pronominals-allow us to draw a firm conclusion: Pronominal production can be taken as a crosslinguistic robust marker of language development. We see that 5-year-old children produce third-person pronominal objects and that the shape and placement of pronominal forms is targetlike. The ability to produce pronominals may be hidden by massive production of null complements in languages allowing for it. However, it is legitimate to conclude from our data that a child who at age 5 is not able to produce any or few pronominal forms is a child at risk for language impairment. In this way, pronominal production can be taken as a developmental marker, provided that one takes into account whether the language allows for null objects.

\section{Acknowledgments}

We would like to thank two anonymous reviewers and the Guest Editor of Language Acquisition for useful comments that helped us improve our paper.

\footnotetext{
${ }^{18}$ One anonymous reviewer raised the issue that the finding (ii) could be an artifact of the restriction of our experiment to thirdperson pronominals, and another result may arise if first- and second-person pronouns/clitics, including reflexives, were tested with a different design. An indication that this finding is not an artifact of the restriction to third-person pronominals is that Costa et al. (2008) elicited dative and reflexive clitics in first- and second-person in European Portuguese, where the null option is not allowed, with a similar design to the design used in this study. It is hard to say whether our findings for third-person pronominals and the findings in Costa et al. (2008) for first- and second-person dative and reflexive clitics are the automatic outcome of the design used, namely elicitation tasks with pictures, as we are not aware of other designs used to elicit pronouns/ clitics.
} 


\section{Funding}

Kleanthes K. Grohmann acknowledges financial support from the University of Cyprus for the GenCHILD Project (8037-61017). The Danish study was supported by a grant from The Danish Agency for Science and Technology and Innovation to Kristine Jensen de López in support of the NASUD project Normal og Atypisk Sproglig Udvikling (Typical and Atypical Language Development) grant \# 09-063957. The Serbian study was supported by the Ministry of Education and Science, Republic of Serbia, Project Fundamentalni kognitivni procesi i funkcije (Fundamental Cognitive Processes and Functions), Grant \# 179033. The Hebrew study was supported by the Lieselotte Adler Laboratory for Research on Child Development and by GIF grant 1113-97.4/2010. The Polish study was partially supported by public funding from the Faculty of Psychology of Warsaw University (grant no BST 184724/09, awarded to Aneta Miękisz) and from the National Science Centre/Ministry of Science and Higher Education (grants no N N106 223538, awarded to Magdalena Smoczyńska and no 809/ N-COST/2010/0, awarded to Ewa Haman). Last, María-José Ezeizabarrena acknowledges financial support from the Ministerio de Ciencia e Innovación for the Spanish data (Grant FFI 2012-37884C03-02) and from The Basque Government (IT-676-13).

\section{References}

Agouraki, Yiorgia. 1997. On the enclisis/proclisis alternation. In Gaberell Drachman, Angeliki Malikouti-Drachman, John Fykias \& Ceila Klidi (eds.), Proceedings of the 2nd International Conference on Greek Linguistics [ICGL 2], 393404. Salzburg: University of Salzburg.

Anagnostopoulou, Elena. 1994. Clitic dependencies in Modern Greek. Salzburg: University of Salzburg dissertation. Ariel, Mira. 1990. Accessing noun-phrase antecedents. London: Routledge.

Avram, Larisa. 1999. Clitic omission in child language and multiple spell-out. Poster presented at the Generative Approaches to Language Acquisition [GALA 1999], September 10-12. University of Potsdam.

Avram, Larisa. 2001. Remarks on the optional clitic stage in child Romanian. Bucharest Working Papers in Linguistics 3 (1). 16-28.

Baauw, Sergio, Peter Coopmans \& William Philip. 1999. The acquisition of pronominal coreference in Spanish and the clitic-pronoun distinction. In Jan Don \& Ted Sanders (eds.), UiL-OTS Yearbook 1998-1999, 1-19. Utrecht University.

Baauw, Sergio, Shalom Zuckerman, Esther Ruigendijk \& Sergey Avrutin. 2011. Principle B delays as a processing problem: Evidence from task effects. In Angela Grimm, Anja Müller, Cornelia Hamann \& Esther Ruigendijk (eds.), Production-comprehension asymmetries in child language, 247-272. Berlin: Mouton De Gruyter.

Babyonyshev, Maria \& Stefania Marin. 2004. Object clitics in child Romanian. In Alejna Brugos, Manuella R. ClarkCotton \& Seungwan Ha (eds.), Proceedings of the 29th annual Boston University Conference on Language Development [BUCLD 29], 49-60. Somerville, MA: Cascadilla Press.

Babyonyshev, Maria \& Stefania Marin. 2006. Acquisition of Romanian pronominal clitics. In Anna Gavarró \& Conxita Lleó (eds.), Catalan Journal of Linguistics 5. 17-44.

Bedore, Lisa M. \& Leonard B. Laurence. 2001. Grammatical morphology deficits in Spanish-speaking children with specific language impairment. Journal of Speech, Language, and Hearing Research 44. 905-924.

Belletti, Adriana. 1999. Italian/Romance clitics: Structure and derivation. In Henk van Riemsdijk (ed.), Clitics in the languages of Europe, 543-579. Berlin: Mouton De Gruyter.

Bloom, Paul. 1990. Subjectless sentences in child language. Linguistic Inquiry 21(4). 491-504.

Bortolini, Umberta, Barbara Arfé, Maria Cristina Caselli, Luisa Degasperi, Patricia Deevy \& Laurence B. Leonard. 2006. Clinical markers for specific language impairment in Italian: The contribution of clitics and non-word repetition. International Journal of Language \& Communication Disorders 41(6). 695-712.

Bošković, Željko. 2001. On the nature of the syntax-phonology interface: Cliticization and related phenomena. NorthHolland Linguistic Series: Linguistic Variations 60. Amsterdam: Elsevier.

Browne, Wayles. 1974. On the problem of enclitic placement in Serbo-Croatian. In Richard D. Brecht \& Catherine Chvany (eds.), Slavic transformational syntax, 36-52. Ann Arbor MI: Michigan Slavic Materials.

Cardinaletti, Anna 1999. Pronouns in Germanic and Romance languages: An overview. In Henk van Riemsdijk (ed.), Clitics in the languages of Europe, 33-82. Berlin: Mouton de Gruyter.

Cardinaletti, Anna \& Michal Starke. 1999. The typology of structural deficiency: A case study of the three classes of pronouns. In Henk van Riemsdijk (ed.), Clitics in the languages of Europe, 145-233. Berlin: Mouton de Gruyter. 
Castilla, Anny P. 2009. Morphosyntactic acquisition in monolingual 3-, 4-, and 5-year-old Spanish-speaking children. In Victoria Marrero \& Idaira Pinera (eds.), Linguistics: The challenge of clinical application. Proceedings of the 2nd International Conference on Clinical Linguistics [ICCL 2], 527-533. Madrid, Spain: Euphonia Ediciones.

Castilla, Anny P., Ana Teresa Pérez-Leroux \& Alice Eriks-Brophy. 2008. Syntax and the lexicon in early omission of Spanish clitics. In Harvey Chan, Heather Jacob \& Enkeleida Kapi (eds.), Proceedings of the 32nd annual Boston University Conference on Language Development. [BUCLD 32], 72-83. Somerville, MA: Cascadilla Press.

Castilla, Anny P. \& Ana Teresa Pérez-Leroux. 2010. Omissions and substitutions in Spanish object clitics: Developmental optionality as a property of the representational system. Language Acquisition 17. 2-25.

Chien, Yu-Chin \& Kenneth Wexler. 1990. Children's knowledge of locality conditions in binding as evidence for the modularity of syntax and pragmatics. Language Acquisition 1. 225-295.

Chillier-Zesiger, Laurence, Marina Arabatzi, Lara Baranzini, Stephany Cronel-Ohayon \& Deonna Thierry. 2006. The acquisition of French pronouns in normal children and in children with specific languageimpairment (SLI). Ms. University of Geneva.

Conroy, Anastasia, Eri Takahashi, Jeffrey Lidz \& Colin Phillips. 2009. Equal treatment for all antecedents: How children succeed with principle B. Linguistic Inquiry 40. 446-486.

Costa, João \& Maria Lobo. 2006. A aquisição de clíticos em PE: omissão de clíticos ou objecto nulo? [The acquisition of clitics in EP: Omission of clitics or null objects?]. In Fatima Oliveira \& Joaquim Barbosa (eds.), XXI Encontro Nacional da Associação Portuguesa de Linguística. Textos selecionados, 285-293. Lisboa: Associação Portuguesa de Linguística.

Costa, João \& Maria Lobo. 2007. Clitic omission, null objects or both in the acquisition of European Portuguese. In Sergio Baauw, Frank Drijkonongen \& Manuela Pinto (eds.), Romance Languages and Linguistic Theory 2005, 59-72. Amsterdam: John Benjamins.

Costa, João \& Maria Lobo. 2011. Assessing children's knowledge of null objects in European Portuguese. Paper presented at the Linguistic Symposium on Romance Languages [LSRL 41], May 5-7, University of Ottawa, Canada.

Costa, João, Maria Lobo, Jaqueline Carmona \& Carolina Silva. 2008. Clitic omission in European Portuguese: Correlation with null objects? In Anna Gavarrò \& M. João Freitas (eds.), Language acquisition and development. Proceedings of Generative Approaches of Language Acquisition 2007 [GALA 2007], 133-143. Newcastle-upon-Tyne: Cambridge Scholars Publishing.

Costa, João, Maria Lobo \& Carolina Silva. 2009. Null objects and early pragmatics in the acquisition of European Portuguese. Probus 21. 143-162.

Cummins, Sarah \&Yves Roberge. 2005. A modular account of null objects in French. Syntax 8. 44-64.

De Villiers, Jill, Jaqueline Cahillane \& Emily Altreuter. 2006. What can production reveal about principle B? In Kamil Ud Deen, Jun Nomura, Barbara Schulz \& Bonnie D. Schwartz (eds.), Proceedings of the Inaugural Conference on Generative Approaches to Language Acquisition - North America, 89-100. Honolulu, HI: University of Connecticut Occasional Papers in Linguistics 4.

Dimitrova-Vulchanova, Mila 1999. Clitics in the Slavic languages. In Henk van Riemsdijk (ed.), Clitics in the languages of Europe, 83-122. Berlin: Mouton de Gruyter.

Duarte, Inês \& Gabriela Matos. 2000. Romance clitics and the minimalist program. In João Costa (ed.), Portuguese syntax: New comparative studies, 116-142. New York: Oxford University Press.

Eisenchlas, Susana. 2003. Clitics in child Spanish. First Language 23(2). 193-211.

Ezeizabarrena, María-José. 1996. Adquisición de la morfología verbal en euskera y castellano por niños bilingües [Bilingual children's acquisition of Basque and Spanish verb morphology]. Bilbao: University of the Basque Country dissertation.

Ezeizabarrena, María-José. 1997. Morfemas de concordancia con el sujeto y los objetos en el castellano infantil [Subject and verb agreement morphemes in early Spanish]. In Ana Teresa Pérez-Leroux \& William R. Glass (eds.), Contemporary perspectives on the acquisition of Spanish, 21-36. Somerville, MA: Cascadilla Press.

Franco, Jon \& Alazne Landa. 2003. Null objects revisited. In Rafael Nuñez-Cedeño, Luis López \& Richard Cameron (eds.), A Romance perspective on language knowledge and use: Selected papers for the 31st Linguistic Symposium on Romance Languages (LSRL), Chicago, 19-22 April 2001, 311-26. Amsterdam: John Benjamins.

Franks, Steven. 2010. Clitics in Slavic. Glossos. The Slavic and East European Language Resource Center $10.1-157$.

Franks, Steven \& Tracy Holloway King. 2000. A handbook of Slavic clitics. New York: Oxford University Press.

Friedmann, Naama. 2007. Young children and A-chains: The acquisition of Hebrew unaccusatives. Language Acquisition 14(4). 377-422.

Fujino, Hanako \& Tetsuya Sano. 2002. Aspects of the null object phenomenon in child Spanish. In Ana Teresa PérezLeroux \& Juana Muñoz Liceras (eds.), The acquisition of Spanish morphosyntax, 67-88. Dordrecht: Kluwer.

Gabriel, Christoph \& Natascha Müller. 2005. Zu den romanischen Pronominalklitika: Kategorialer Status und syntaktische Derivation [On Romance pronominal clitics: Categorial status and syntactic derivation]. In Georg Kaiser (ed.), Deutsche Romanistik - generativ, 161-180. Tübingen: Narr.

Gavarró, Anna, Meritxell Mata \& Eulàlia Ribera. 2006. L'omissió dels clítics d'objecte i partitius en el català infantil: dades espontànies [Omission of object and partitive clitcs in child Catalan: spontaneous data]. In Claus D. Pusch 
(ed.), Zeitschrift für katalanistik, special volume La gramàtica pronominal del català - Variació, evolució, funció [The grammar of Catalan pronouns - Variation, evolution, function], 27-46. Aachen: Shaker Verlag.

Gavarró, Anna \& Marta Mosella. 2009. Testing syntactic and pragmatic accounts of clitic omission. In Jean Crawford, Koichi Otaki \& Masahiko Takahashi (eds.), Proceedings of the 3rd Conference on Generative Approaches to Language Acquisition North America [GALANA 3], 25-35. Somerville, MA: Cascadilla Proceedings Project.

Gavarró, Anna, Vicent Torrens \& Kenneth Wexler. 2010. Object clitic omission: Two language types. Language Acquisition 17(4). 192-219.

Gerken, Lou Ann. 1996. Phonological and distributional information in syntax acquisition. In James L. Morgan \& Katherine Demuth (eds.), Signal to syntax: Bootstrapping from speech to grammar in early acquisition, 411-425. Mahwah, NJ: Lawrence Erlbaum Associates.

Grohmann, Kleanthes K. 1997. Pronouns and the left periphery of West Germanic embedded clauses. In Abraham Werner \& Elly van Gelderen (eds.), German: Syntactic problems - Problematic syntax, 163-189. Tübingen: Niemeyer.

Grohmann, Kleanthes K. 2011. Some directions for the systematic investigation of the acquisition of Cypriot Greek: A new perspective on production abilities from object clitic placement. In Esther Rinke and Tanja Kupisch (eds.), The development of grammar: Language acquisition and diachronic change, 179-203. Amsterdam: John Benjamins.

Grohmann, Kleanthes K. \& Evelina Leivada. 2012. Interface ingredients of dialect design: Bi-x, socio-syntax of development, and the grammar of Cypriot Greek. In Anna Maria Di Sciullo (ed.), Towards a biolinguistic understanding of grammar: Essays on interfaces, 239-262. Amsterdam: John Benjamins.

Grohmann, Kleanthes K., Eleni Theodorou, Natalia Pavlou, Evelina Leivada, Elena Papadopoulou \& Silvia MartínezFerreiro. 2012. The development of object clitic placement in Cypriot Greek and the Romance connection. In Sadrine Ferré, Philippe Prévost, Laurice Tuller \& Rasha Zebib (eds.), Selected Proceedings of the Romance Turn IV, 128-152. Newcastle-upon-Tyne: Cambridge Scholars Publishing.

Grüter, Theres. 2005. Comprehension and production of French object clitics by child second language learners and children with specific language impairment. Applied Psycholinguistics 26. 363-391.

Grüter, Theres. 2006. Object clitics and null objects in the acquisition of French. Montréal: McGill University dissertation.

Grüter, Theres. 2007. Investigating object drop in child French and English: A truth value judgment task. In Belikova Alyona, Luisa Meroni \& Mari Umeda (eds.), Proceedings of the 2nd Conference on Generative Approaches to Language Acquisition North America [GALANA 2], 102-113. Somerville, MA: Cascadilla Proceedings Project.

Guasti, Maria Teresa. 1993-1994. Verb syntax in Italian child grammar: Finite and nonfinite verbs. Language Acquisition 3. 1-40.

Gundel, Jeanette K., Nancy Hedberg \& Ron Zacharski. 1993. Cognitive status and the form of refeering expressions in discourse. Language 69. 274-307.

Hamann, Cornelia \& Adriana Belletti. 2006. Developmental patterns in the acquisition of complement clitic pronouns. Comparing different acquisition modes with an emphasis on French. Rivista di Grammatica Generativa 31. 39-78.

Hamann, Cornelia, Luigi Rizzi \& Uli H. Frauenfelder. 1996. On the acquisition of the pronominal system in French. In Harald Clahsen (ed.), Generative perspectives on language acquisition, 309-334. Amsterdam: John Benjamins.

van Hout, Angeliek, Alma Veenstra \& Sanne Berends. 2011. All pronouns are not acquired equally in Dutch: Elicitation of object and quantitative pronouns. In Mihaela Pirvulescu, María Cristina Cuervo, Ana Teresa PérezLeroux, Jeffrey Steele \& Nelleke Strik (eds.), Selected Proceedings of the 4th Conference on Generative Approaches to Language Acquisition North America [GALANA 4], 106-121. Somerville MA: Cascadilla Proceedings Project.

Hyams, Nina \& Kenneth Wexler. 1993. The grammatical basis of null subjects in child language. Linguistic Inquiry 24. 421-459.

Ilic, Tatjana \& Kamil Ud Deen. 2004. Object raising and cliticization in Serbo-Croatian child language. In Jacqueline van Kampen \& Sergio Baauw (eds.), Proceedings of 5th Generative Approaches to Language Acquisition [GALA 5], 235-243. LOT.

Jakubowicz, Celia, Natascha Müller, Ok-Kyung Kang, Beate Riemer \& Catherine Rigaut. 1996. On the acquisition of the pronominal system in French and German. In Andy Stringfellow, Dalia Cahana-Amitay, Elizabeth Hughes \&Andrea Zukowski (eds.), Proceedings of the 20th annual Boston University Conference on Language Development [BUCLD 20], 374-385. Somerville MA: Cascadilla Press.

Jakubowicz, Celia \& Lea Nash. Forthcoming. Why accusative clitics are avoided in normal and impaired language development. In Celia Jakubowicz, Lea Nash \& Kenneth Wexler (eds.), Essays in syntax, morphology and phonology in SLI. Cambridge, MA: MIT Press.

Jakubowicz, Celia, Natascha Müller, Beate Riemer \& Catherine Rigaut. 1997. The case of subject and object omission in French and German. In Elizabeth Hughes, Mary Hughes \& Annabel Greenhill (eds.), Proceedings of the 21st annual Boston University Conference on Language Development [BUCLD 21], 331-342. Somerville MA: Cascadilla Press.

Jakubowicz, Celia, Lea Nash, Catherine Rigaut \& Christophe-Loic Gerard. 1998. Determiners and clitic pronouns in French-speaking children with SLI. Language Acquisition 7. 113-160.

Jakubowicz, Celia \& Catherine Rigaut. 2000. L'acquisition des clitiques nominatifs et des clitiques objets en Français [The acquisition of nominative and object clitics in French]. The Canadian Journal of Linguistics 45. 119-158.

Kayne, Richard. 1975. French syntax. Cambridge, MA: MIT Press. 
Kayne, Richard.1991. Romance clitics, verb movement, and PRO. Linguistic Inquiry 22. 647-686 (reprinted in: Richard Kayne, 2000. Parameters and universals, 60-97. Oxford: Oxford University Press).

Laenzlinger, Christopher \& Ur Shlonsky. 1997. Weak pronouns as LF clitics: Clustering and adjacency effects in the pronominal systems of German and Hebrew. Studia Linguistica 51(2). 154-185.

Larrañaga, María Pilar. 2000. Ergative Sprachen, akkusative Sprachen. Der Erwerb des Kasus bei bilingualen Kindern [Ergative languages, accusative languages: The acquisition of case in bilingual children]. Frankfurt am Main: Vervuert.

Larrañaga, María Pilar \& Pedro Guijarro-Fuentes. 2011. Clitics in L1 bilingual acquisition. First Language 31(4). 1-25.

Lyczkowski, David. 1999. Adquiéretelo: On the acquisition of pronominal object clitics in Spanish. Cambridge, Massachusetts: Harvard University MA thesis.

Marinis, Theodoros. 2000. The acquisition of clitic objects in Modern Greek: Single clitics, clitic doubling, clitic left dislocation. ZAS Working Papers 15. 259-281.

Manika, Sophia, Spyridoula Varlokosta \& Kenneth Wexler. 2011. The lack of omission of clitics in Greek children with SLI: An experimental study. In Nick Danis, Kate Mesh \& Hyunsuk Sung (eds.), Proceedings of the 35th annual Boston University Conference on Language Development [BUCLD35], 427-439. Somerville, MA: Cascadilla Press.

McKee, Cecile. 1992. A comparison of pronouns and anaphors in Italian and English acquisition. Language Acquisition 2. 21-54.

Müller, Gereon. 2001. Harmonic alignment and the hierarchy of pronouns in German. In Horst J. Simon \& Heike Wiese (eds.), Pronouns - grammar and representation, 205-232. Amsterdam: Benjamins.

Novogrodsky, Rama, Noga Balaban \& Naama Friedmann. 2010. When the child says that daddy hugs him, whom does he hug? On the development of the comprehension and production of pronouns in Hebrew. Language and Brain 10. 1-19. (in Hebrew)

Paradis, Johanne, Martha Crago \& Fred Genesee. 2003. Object clitics as a clinical marker of SLI in French: Evidence from French-English bilingual children. In Barbara Beachley, Amanda Brown \& Frances Conlin (eds.), Proceedings of the 27th annual Boston University Conference on Language Development [BUCLD 27], 638-649. Somerville, MA: Cascadilla Press.

Pérez-Leroux, Ana Teresa, Mihaela Pirvulescu \& Yves Roberge. 2008(a). Children's interpretation of null objects under the scope of negation. In Susie Jones (ed.), Proceedings of the 2008 Annual Conference of the Canadian Linguistic Association. Vancouver: University of British Columbia, 1-10.

Pérez-Leroux, Ana Teresa, Mihaela Pirvulescu \& Yves Roberge. 2008(b). Null objects in child language: Syntax and the lexicon. Lingua 118(3). 370-398.

Petinou, Kakia \& Arhonto Terzi. 2002. Clitic misplacement in normally developing and language impaired CypriotGreek speaking children. Language Acquisition 10. 1-28.

Pirvulescu, Mihaela. 2006. Theoretical implications of object clitic omission in early French: spontaneous vs. elicited production. Catalan Journal of Linguistics 5. 221-236.

Raposo, Eduardo.1986. On the null object construction in European Portuguese. In Osvaldo Jaeggli \& Carmen SilvaCorvalán (eds.), Studies in romance linguistics, 373-390. Dordrecht: Foris.

Ruigendijk, Esther, Naama Friedmann, Rama Novogrodsky \& Noga Balaban. 2010. Symmetry in comprehension and production of pronouns: A comparison of German and Hebrew. Lingua 120(8). 1991-2005.

Schaeffer, Jeannette. 1997. Direct object scrambling in Dutch and Italian child language. Los Angeles: University of California dissertation.

Schaeffer, Jeannette. 2000. The acquisition of direct object scrambling and clitic placement. Amsterdam/Philadelphia: John Benjamins.

Schmitz, Katrin \& Natascha, Müller. 2008. Strong and clitic pronouns in monolingual and bilingual acquisition of French and Italian. Bilingualism: Language and Cognition 11(1). 19-41.

Silva, Carolina. 2008. Assimetrias na aquisição de clíticos diferenciados em português europeu [Asymmetries in the acquisition of different types of clitics in European Portuguese]. Lisboa: Universidade Nova de Lisboa MA thesis.

Smith, Nafsika, Susan Edwards, Vesna Stojanovik \& Spyridoula Varlokosta. 2008. Object clitics, definite articles and genitive possessive clitics in Greek specific language impairment (SLI): Deficits and explanations. In Theodoros Marinis, Angeliki Papangeli \& Vesna Stojanovik (eds.), Proceedings of the 2007 Child Language Seminar, 30th Anniversary, 146-156. University of Reading.

Spenader, Jennifer, Erik-Jan Smits \& Petra Hendriks. 2009. Coherent discourse solves the pronoun interpretation problem. Journal of Child Language 36(1). 23-52.

Sportiche, Dominique.1996. Clitic constructions. In Johan Rooryck \& Laurie Zaring (eds.), Phrase structure and the lexicon, 213-276. Dordrecht: Kluwer Academic.

Stavrakaki, Stavroula \& Heather van der Lely. 2010. Production and comprehension of pronouns by Greek children with specific language impairment. British Journal of Developmental Psychology 28. 189-216.

Tedeschi, Roberta. 2009. Acquisition at the interfaces. A case study on object clitics in early Italian. Utrecht: University of Utrecht dissertation.

Terzi, Arhonto 1999. Cypriot Greek clitics and their positioning restrictions. In Artemis Alexiadou, Geoffrey Horrocks \& Melita Stavrou (eds.), Studies in Greek syntax, 227-240. Dordrecht: Kluwer. 
Tsakali, Vina \& Wexler Kenneth. 2003. Why children omit clitics in some languages but not in others: New evidence from Greek. Paper presented at the Generative Approaches to Language Acquisition [GALA 2003], September 4-6. University of Utrecht, Utrecht, The Netherlands.

Tsakali, Vina \& Wexler Kenneth. 2004. Why children omit clitics in some languages, but not in others: New evidence from Greek. In Kampen Jacqueline \& Sergio Baauw (eds.), Proceedings of Generative Approaches to Language Acquisition [GALA 2003], 493-504. LOT.

Tsimpli, Ianthi Maria \& Stavroula Stavrakaki. 1999. The effects of a morphosyntactic deficit in the determiner system: The case of a Greek SLI child. Lingua 108. 31-86.

Tuller, Laurice. 2000. Aspects de la morphosyntaxe du français des sourds [Aspects of morphosyntax in deaf French]. Recherches Linguistiques de Vincennes 29. 143-156.

Tuller, Laurice, Hélène Delage, Cécile Monjauze, Anna-Gaëlle Piller \& Marie-Anne Barthez. (2011). Clitic pronoun production as a measure of atypical language development in French. Lingua 121(3). 423-441.

Uriagereka, Juan. 1995. Aspects of the syntax of clitic placement in Western Romance. Linguistic Inquiry 26. 79-123.

Valian, Virginia. 1991. Syntactic subjects in the early speech of American and Italian children. Cognition 40. 21-81.

Vanderweide, Teresa. 2005. The acquisition of manner in pre-vocalic sequences: A cue is a cue. In Marina Tzakosta, Claartje Levelt \& Jeroen van de Weijer (eds.), Developmental paths in phonological acquisition. Special Issue of Leiden Papers in Linguistics 2(1).137-161.

Varlokosta, Spyridoula. 2000. Lack of clitic pronoun distinctions in the acquisition of principle B in child Greek. In S. Catherine Howell, Sarah A. Fish \& Thea Keith-Lucas (eds.), Proceedings of the 24th annual Boston University Conference on Language Development [BUCLD 24], 738-748. Somerville, MA: Cascadilla Press.

Varlokosta, Spyridoula, Katerina Konstantzou \& Michaela Nerantzini. 2014. On the production of direct object clitics in Greek typical development and specific language impairment: The effect of task selection. In Kleanthes K. Grohmann \& Theoni Neokleous (eds.), Developments in the acquisition of clitics, 188-211. Newcastle Upon Tyne: Cambridge Scholars Publishing.

Wexler, Kenneth, Anna Gavarró \& Vicent Torrens. 2004. Feature checking and object clitic omission in child Catalan and Spanish. In Reineke Bok-Bennema, Bart Hollebrandse, Brigitte Kampers-Manhe \& Petra Sleeman (eds.), Romance languages and linguistic theory 2002, 253-70. Amsterdam: John Benjamins.

Zwart, C. Jan-Wouter. 1991. Clitics in Dutch: Evidence for the position of INFL. Groninger Arbeitenzur Germanistischen Linguistik 33. 71-92.

Zwicky, Arnold M. 1977. On clitics. Bloomington: Indiana University Linguistics Club.

\section{Appendix A}

Examples of sentences used to accompany the picture in Figure 1, for all the languages tested.

(1) a. preverbal clitic

Catalan

El nen ruixa el gat i el gat està moll.

the boy sprays the cat and the cat is wet

Com és que el gat està moll?

how is that the cat is wet

El gat està moll perquè el nen el ruixa.

the cat is wet because the boy CL.ACC.3sG wet.PRES.3SG

French

Le garçon arrose le chat et le chat est mouillé.

the boy sprays the cat and the cat is wet

Pourquoi est-ce-que le chat est si mouillé?

why is-it-that the cat is so wet

Le chat est mouillé parce que le garçon l'arrose.

the cat is wet because the boy CL.ACC.3SG spray.PRES.3sG

Italian

Il bambino sta bagnando il gatto ed il gatto è bagnato.

the boy is wetting the cat and now the cat is wet

Perché il gatto è così bagnato?

why the cat is so wet

Il gatto è bagnato perche il bambino lo bagna/ sta bagnando.

the cat is wet because the boy CL.ACC.3sG.MASC wet.PRES.3sG/ is wetting 


\section{Romanian}

Băiatul stropeşte/udă pisica şi pisica e udă.

boy.the sprays cat.the and cat.the is wet

De ce e pisica aşa udă?

why is cat.the that wet

Pisica e udă pentru că o stropeşte/udă băiatul.

cat.the is wet because CL.ACC.3SG.FEM spray.PRES.3sG boy.the

Spanish

El niño está mojando a-l gato y ahora el gato está mojado.

the boy is weting to-the cat and now the cat is wet.MASC

¿Por qué está mojado el gato?

why is wet.MAsc the cat

El gato está mojado porque el niño lo ha mojado.

The cat is wet.MASC because the child CL.ACC.3sG.MASC has wetted

Standard Modern Greek

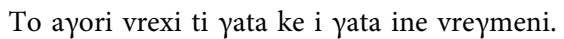

the boy wets the cat and the cat is wet

Jati ine vreymeni i $\gamma$ ata?

why is wet the cat

I $\gamma$ ata ine vreymeni jati to ayori tin vrexi.

the cat is wet because the boy CL.ACC.3SG.FEM wet.PRES.3SG

b. postverbal clitic

\section{Cypriot Greek}

To ayori vre $\int \mathrm{i}$ ti $\gamma$ ata $\mathrm{t} \int \mathrm{e}$ i $\gamma$ ata e vremeni.

the boy wets the cat and the cat is wet

Jati i $\gamma$ ata e vremeni?

why the cat is wet

I $\gamma$ ata e vremeni jati to ayori vre $\int i$ tin.

the cat is wet because the boy wet.PRES.3SG CL.ACC.3SG.FEM

\section{European Portuguese}

O menino molhou o gato e o gato está molhado.

the boy wet.PAST. the cat and the cat is wet

Porque é que o gato está molhado?

why is that the cat is wet

$\mathrm{O}$ gato está molhado porque o menino o molhou.

the cat is wet because the boy CL.ACC.3sG.MASC wet.PAST.3sG

c. second-position clitic

\section{Croatian}

Dječak prska mačku i mačka je mokra.

boy sprays cat and cat is wet

Zašto je mačka mokra?

why is cat wet

Mačka je mokra zato što ju je dječak poprskao.

cat is wet because CL.ACC.3SG.FEM be.AUx boy spray.PERF.3SG

Polish

Chłopiec ochlapuje kota i kot jest mokry.

boy sprays cat and cat is wet

Dlaczego kot jest mokry?

why cat is wet

Kot jest mokry bo chłopiec ochlapuje go.

cat is wet because boy spray.PRES.3SG CL.ACC.3sG.MASC 
Serbian

Dečak poliva mačku i mačka je mokra.

boy wets cat and cat is wet

Zašto je mačka mokra?

why is cat wet

Mačka je mokra zato što je dečak poliva.

cat is wet because CL.ACC.3SG.FEM boy wet.PREs.3sG

(2) pronoun

\section{Danish}

Dreng-en sprøjter på katt-en og katt-en er våd.

boy-the spray on cat-the and cat-the is wet

Hvorfor er katt-en våd?

why is cat-the wet

Katt-en er våd fordi dreng-en sprøjter på den.

cat-the is wet because boy-the spray.PRES on PRON.COMMON.3sG

Dutch

De jongen spuit de poes nat en nu is de poes nat.

the boy sprays the cat wet and now is the cat wet

Hoe komt het dat de poes nat is?

how comes it that the cat wet is

De poes is nat omdat de jongen ' $m$ nat heeft gespoten.

the cat is wet because the boy PRON.ACC.3SG.MASC wet has sprayed

German

Der Junge spritzt die Katze nass und die Katze ist sehr nass.

the boy sprays the cat wet and the cat is very wet

Wieso ist die Katze so nass?

why is the cat so wet

Die Katze ist so nass, weil der Junge die/sie nass spritzt.

the cat is so wet because the boy PRON.ACC.3sG.FEM wet sprays

\section{Hebrew}

Ha-yeled hirtiv et ha-xatul ve-axshav ha-xatul ratuv.

the-boy wet ACC the-cat and-now the-cat wet

Lama ha-xatul ratuv?

why the-cat wet

Ha-xatul ratuv ki ha-yeled hirtiv oto.

the-cat wet because the-boy wet.PAST.3SG.MASC PRON.ACC.3sG.MASC 


\section{Appendix B}

Verbs, pictures, and lead-In sentences for the english experiment

\begin{tabular}{|c|c|c|}
\hline Verb & Picture description & Experimenter \\
\hline cover & ng & $\begin{array}{l}\text { The princess covered the soldier. No } \\
\text { the soldier warm? The soldier is war }\end{array}$ \\
\hline comb & $\begin{array}{l}\text { mother con } \\
\text { girl's hair }\end{array}$ & $\begin{array}{l}\text { Mommy is combing the girl, and the } \\
\text { beautiful? The girl is beautiful becau }\end{array}$ \\
\hline dry & boy drying hippo & $\begin{array}{l}\text { The boy is drying the hippo. The } \\
\text { hippo getting dry? The hippo is }\end{array}$ \\
\hline $\begin{array}{l}\text { wake } \\
\text { up }\end{array}$ & girl & $\begin{array}{l}\text { boy is crying. Why is the } \\
\text { girl .... }\end{array}$ \\
\hline draw & $\begin{array}{l}\text { drawer/man } \\
\text { drawing girl }\end{array}$ & $\begin{array}{l}\mathrm{d} \text { the girl is happy. Why is the } \\
\text { the drawer/man ... }\end{array}$ \\
\hline wet & $\begin{array}{l}\text { boy } \\
\text { with }\end{array}$ & ret. Why is the cat so wet? \\
\hline paint & $\begin{array}{l}\text { pair } \\
\text { pair }\end{array}$ & $\begin{array}{l}\text { se, and it became blue. Why is the } \\
\text { cause the painter/man ... }\end{array}$ \\
\hline lick & dog & Why is the cat \\
\hline tie & $\begin{array}{l}\text { bee tying up } \\
\text { grasshopper }\end{array}$ & $\begin{array}{l}\text { The bee tied up the grasshopper, and the grasshopper cannot jump. } \\
\text { Why can't the grasshopper jump? The grasshopper can't jump } \\
\text { because the bee ... }\end{array}$ \\
\hline wash & girl washing giraffe & clean. Why is the \\
\hline eat & $\begin{array}{l}\text { boy eating a piece of } \\
\text { the cake }\end{array}$ & $\begin{array}{l}\text { The boy ate a piece of the cake, and that piece of the cake } \\
\text { disappeared! Why did the piece of the cake disappear? The piece of } \\
\text { cake disappeared because the boy ... }\end{array}$ \\
\hline catch & $\begin{array}{l}\text { girl catching } \\
\text { butterfly }\end{array}$ & $\begin{array}{l}\text { The girl caught the butterfly, and the butterfly cannot fly. Why can't } \\
\text { the butterfly fly? The butterfly can't fly because the girl ... }\end{array}$ \\
\hline
\end{tabular}




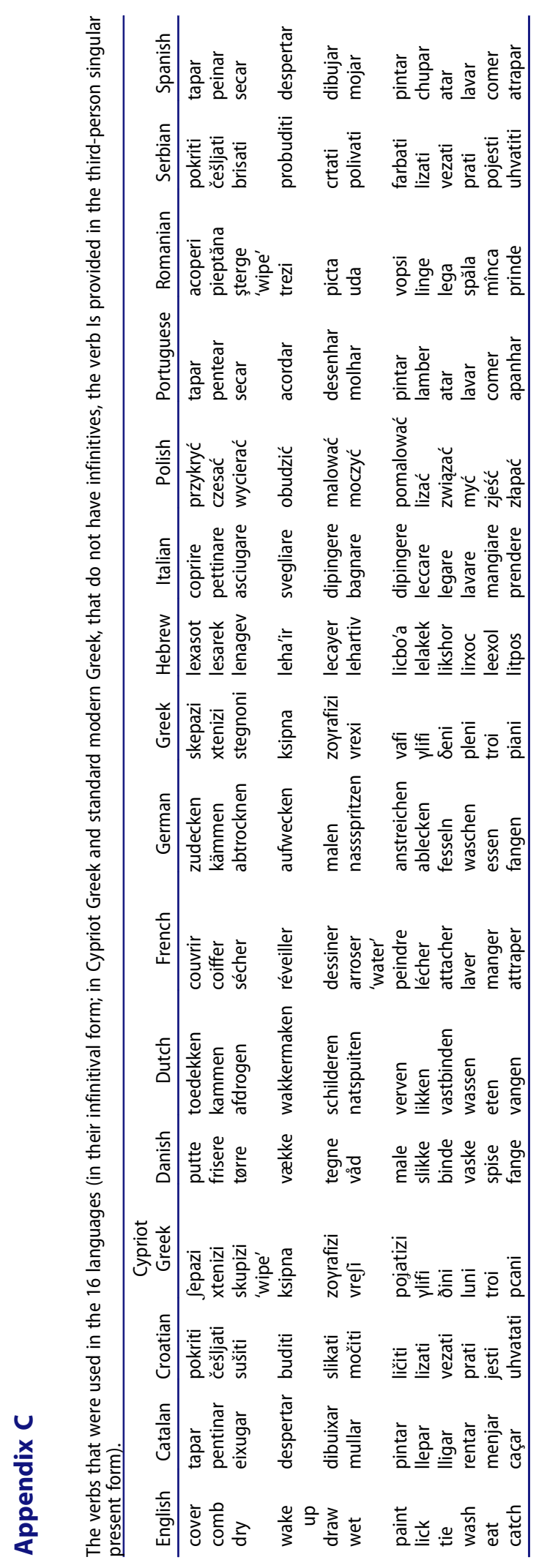

